\title{
Metric and morphological study of the upper cervical spine from the Sima de los Huesos site (Sierra de Atapuerca, Burgos, Spain)
}

\author{
Asier Gómez-Olivencia a,b,*, José Miguel Carretero ${ }^{\mathrm{a}, \mathrm{b}}$, Juan Luis Arsuaga ${ }^{\mathrm{b}, \mathrm{c}}$, \\ Laura Rodríguez-García $^{\text {a,b }}$, Rebeca García-González ${ }^{\text {a,b }}$, Ignacio Martínez ${ }^{\text {b,d }}$

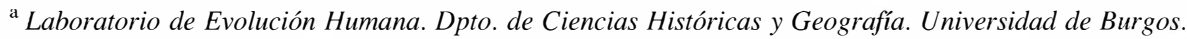 \\ Edificio I+D+i. Plaza Misael de Bañuelos s/n. 09001 Burgos, Spain \\ ${ }^{\mathrm{b}}$ Centro UCM-ISCIII de Investigación sobre Evolución y Comportamiento Humanos, c/Sinesio Delgado, 4 (Pabellón 14), 28029 Madrid, Spain \\ ${ }^{\mathrm{c}}$ Departamento de Paleontología, Facultad de Ciencias Geológicas, Universidad Complutense de Madrid, Ciudad Universitaria s/n, 28040 Madrid, Spain \\ 'Departamento de Geología, Universidad de Alcalá, Edificio de Ciencias, Campus Universitario, 28871 Alcalá de Henares, Spain
}

\begin{abstract}
In this article, the upper cervical spine remains recovered from the Sima de los Huesos (SH) middle Pleistocene site in the Sierra de Atapuerca (Burgos, Spain) are described and analyzed. To date, this site has yielded more than 5000 human fossils belonging to a minimum of 28 individuals of the species Homo heidelbergensis. At least eleven individuals are represented by the upper cervical (C1 and C2) specimens: six adults and five subadults, one of which could represent an adolescent individual. The most complete adult vertebrae (three atlases and three axes) are described, measured, and compared with other fossil hominins and modern humans. These six specimens are associated with one another and represent three individuals. In addition, one of these sets of cervical vertebrae is associated with Cranium 5 (Individual XXI) from the site. The metric analysis demonstrates that the Sima de los Huesos atlases and axes are metrically more similar to Neandertals than to our modern human comparative sample. The SH atlases share with Neandertals a sagittally elongated canal. The most remarkable feature of the SH (and Neandertal) axes is that they are craniocaudally low and mediolaterally wide compared to our modern male sample. Morphologically, the SH sample shares with Neandertals a higher frequency of caudally projected anterior atlas arch, which could reflect greater development of the longus colli muscle. In other features, such as the frequency of weakly developed tubercles for the attachment of the transverse ligament of the atlas, the Sima de los Huesos fossils show intermediate frequencies between our modern comparative samples and the Neandertals, which could represent the primitive condition. Our results are consistent with the previous phylogenetic interpretation of $H$. heidelbergensis as an exclusively European species, ancestral only to $H$. neanderthalensis.
\end{abstract}

Keywords: Atlas; Axis; Cervical vertebrae; Middle Pleistocene; Sima de los Huesos

\section{Introduction}

The Sima de los Huesos (SH) site is approximately $0.5 \mathrm{~km}$ from the Cueva Mayor entrance, well inside the Cueva MayorCueva del Silo cave system in the Sierra de Atapuerca in northern Spain (Arsuaga et al., 1997b). To date, more than 5000 fossil human remains have been recovered from the site (Arsuaga and Martínez, 2004) in the excavations directed by one of us (JLA). Based on dental evidence, these remains belong to a minimum number of 28 individuals (Bermúdez de Castro et al., 2004) of both sexes and diverse ages. In addition, thousands of carnivore bones have been recovered mixed with and stratigraphically above the human fossils (García et al., 1997; García, 2002). All anatomical parts of the skeleton are represented among the human remains, suggesting that 
complete corpses were accumulated at this site. The ageat-death distribution suggests that a nonattritional demøgraphic event affected this living population (Bøcquet-Appel and Arsuaga, 1999; Bermúdez de Castr et al., 2004). The •rigin -f the human accumulation is most likely to be anthropgenic (Arsuaga et al., 1997b). A recently discovered handaxe has been interpreted as evidence of symbolic behavior in these early humans (Carbonell et al., 2003).

A recently found in situ spele them (SRA-3), which seals the human-fossil-bearing sediments throughout the site, has been dated. There is a hiatus in the speleothem growth at about $4 \mathrm{~cm}$ below the top. This upper portion shows a linear growth rate $\bullet$ abøut $1 \mathrm{~cm}$ per 32,000 years. Ten dates have been $\bullet b-$ tained in the lower $10 \mathrm{~cm}$ of speleothem below the hiatus, all -f which indicate a minimum age of $350 \mathrm{ka}$, although this thickness could represent a significant amount of time beyond this date. Thus, a range of $400-500 \mathrm{ka}$ has been proposed for the human remains (Bischøff et al., 2003). These dates are compatible with both the micro- and macromammalian assemblages (Cuenca-Bescós et al., 1997; García et al., 1997; García, 2002). Bischøf et al. (2006) recently published a reanalysis of six samples of SRA-3 using inductively coupled plasmamultic llect $\bullet$ mass-spectrometry (ICP-MS), which yielded new dates that cluster around $600 \mathrm{ka}$, with an estimated minimum age $\bullet$ the speleothem, and thus of the underlying human fossils, of $530 \mathrm{ka}$.

The human remains from this site have been assigned to Homo heidelbergensis. This species, in our view, is exclusively Eurøpean, and is ancestral only to the later Neandertals (Arsuaga et al., 1991, 1997c; Carreter et al., 1997; Martínez and Arsuaga, 1997).

The record of the upper cervical vertebral column is relatively abundant for Homo neanderthalensis and late Pleistocene Homo sapiens, but with respect to the rest $\bullet$ the genus Homo, it is scarce or nonexistent. ${ }^{1}$ The virtual absence of a fossil record of the upper cervical spine for the middle Pleistocene underscores the importance of the $\mathrm{SH}$ specimens described and analyzed here.

Regarding the Neandertals, the most conspicuøus traits described for the atlas vertebra (Cl) are (1) weakly developed tubercles for the insertion of the transverse ligament and (2) a caudal projection of the anterior tubercle (Bøule, 19111913; Martin, 1923; Heim, 1976; Arensburg, 1991); for the Neandertal axis (C2) n॰ trait $\bullet$ r pattern has been highlighted except its great mørphøløgical variability (Piveteau, 1966). In his study -f the cervical spine of the Kebara 2 Neandertal individual, Arensburg (1991) concluded that, except for the horizontal spinous process of the $\mathrm{C} 6$ and $\mathrm{C} 7$, the cervical column seemed to be within the range of variation of modern human populations. Nevertheless, the study of the middle Pleistocene SH upper cervical vertebrae ( $\mathrm{Cl}$ and $\mathrm{C} 2)$ may reveal some previously

\footnotetext{
${ }^{1}$ The exceptions are the specimens from Dmanisi (Meyer, 2005), Gran Dolina (Carretero et al., 1999), and Koobi Fora (KNM-ER 1808; Walker et al., 1982; Leakey and Walker, 1985) for the early Pleistocene and, for the middle Pleistocene, the atlas from the Zhoukoudian I1 individual (Boaz et al., 2004)
}

undøcumented mørphølogical features and/or patterns $\bullet$ variation within the Neandertal evolutionary lineage.

The first part $\bullet$ the study comprises the inventory of all the atlases and axes, with the determination (if possible) of the age at death (Tables 3 and 4 ) and the ninimum number of individuals represented among the remains. A brief description of the most complete adult vertebrae is alsø provided. In the second part, we perform a metrical analysis of the adult vertebrae and compare the anatomical features present in the SH specimens with those found in other samples of Homo, especially H. neanderthalensis and $H$. sapiens.

\section{Materials}

The SH vertebral sample comprises 455 fossils that represent at least 180 vertebrae. The cervical sample consists of 116 fossils (Gómez-Olivencia, 2005), including 22 first cervical vertebrae (atlas) and 16 second cervical vertebrae (axis). The present study includes the atlas $(\mathrm{C} 1)$ and axis (C2) remains recovered up through the 2004 field season. An inventory and photographic documentation of all the fossil material, as well as short descriptions and merical data of the most complete adult vertebrae, are provided.

Descriptions of a few of the cervical vertebrae [including the atlas VC3 (AT-1554) and a general description of the SH cervical vertebrae] have been published previously (Carreter et al., 1999; Gómez et al., 2005). The present study provides a detaile analysis of the SH upper cervical spine. Appendix 1 provides information on the labeling of the SH vertebrae.

For comparative purposes we have studied a large sample of modern human skeletons and fossil hominin specimens from the following species: $H$. antecessor, $H$. neanderthalensis, and late Pleistocene $H$. sapiens (Table 1 ). Althøugh remains -f the atlas and axis are alsø known from the Mousterian site -f Qafzeh (Vandermeersch, 1981), their fragmentary nature makes comparison with these specimens difficult. Data for the following specimens have been taken from the literature: Kebara 2 (Arensburg et al., 1990; Arensburg, 1991), Régøurdou 1 (Piveteau, 1966), Shanidar 2 and 4 (Stewart, 1962; Trinkaus, 1983), Subalyuk (Pap et al., 1996), and Dølní Věst•nice 14 (Sládek et al., 2000).

\section{Methods}

We used standard anthropometric techniques and instruments to take all measurements. The meric variables are illusrated in Fig. 1. Følløwing Meyer (2005), the areas of vertebral canals were measured on scaled digital images and crosschecked for accuracy by comparing imaged linear measurements to physical dimensions measured with digital calipers. This method avoids the considerable error of area estimation by simply multiplying the dorsoventral and transverse diameters of the neural canal (Meyer, 2005). Vertebral-canal areas were measured on cranial (atlas) and caudal (axis) photographs using CAD software and cross-checked using the canal's maximum transverse diameter (M11). For the atlas, the photograph was taken in superior view. 
Comparative specimens and samples of atlases and axes measure by the authors

\begin{tabular}{|c|c|c|c|c|}
\hline Specimen/sample & Species & Sex & Original/cast & Location \\
\hline ATD6-90 (C1) & H. antecessor & Female & Original & Museo de Burgos, Burgos (Spain) \\
\hline Krapina $(\mathrm{C} 1, n=3 ; \mathrm{C} 2, n=3)$ & H. neanderthalensis & $?$ & Original & $\begin{array}{l}\text { Croatian Natural History Museum, } \\
\text { Zagreb (Croatia) }\end{array}$ \\
\hline La Chapelle-aux-Saints ( $\mathrm{Cl}$ and $\mathrm{C} 2)$ & H. neanderthalensis & Male & Original & Musée de l'Homme, Paris (France) \\
\hline La Ferrassie 1 ( $\mathrm{Cl}$ and $\mathrm{C} 2)$ & H. neanderthalensis & Male & Original & Musée de l'Homme, Paris (France) \\
\hline Shanidar $2(\mathrm{Cl}$ and $\mathrm{C} 2)$ & H. neanderthalensis & Male & Cast & Musée de l'Homme, Paris (France) \\
\hline Skhul V (Cl and $\mathrm{C} 2)$ & H. sapiens & Male & Original & $\begin{array}{l}\text { Peabody Museum of Archaeology and } \\
\text { Ethmology, Cambridge (MA, USA) }\end{array}$ \\
\hline Arcy-sur-C ure, Grotte des Fées ( $\mathrm{C} 1$ and $\mathrm{C} 2)$ & H. sapiens $(?)^{1}$ & $?$ & $\begin{array}{l}\text { Original }(\mathrm{C} 1) \\
\text { Cast }(\mathrm{C} 2)\end{array}$ & $\begin{array}{l}\text { Musée de l'Homme, Paris (France) (C1) } \\
\text { Institut de Paléontologie Humaine, } \\
\text { Paris (France) (C2) }\end{array}$ \\
\hline Cro-Magnon (Cl) & H. sapiens & Male & Original & Musée de l'Homme, Paris (France) \\
\hline Carolingian $^{2}(\mathrm{C} 2, n=4)$ & $H$. sapiens & 7 & Original & Musée de l'Homme, Paris (France) \\
\hline Neolithic $^{3}(\mathrm{C} 2, n=2)$ & $H$. sapiens & $?$ & Original & Musée de l'Homme, Paris (France) \\
\hline Afalou-Bou-Rhummel ${ }^{4}(\mathrm{C} 1, n=12 ; \mathrm{C} 2, n=1 \bullet)$ & H. sapiens & $?$ & Original & $\begin{array}{l}\text { Institut de Paléontologie Humaine, } \\
\text { Paris (France) }\end{array}$ \\
\hline $\operatorname{Taforalt}^{5}(\mathrm{C} 1, n=8 ; \mathrm{C} 2, n=9)$ & H. sapiens & $?$ & Original & $\begin{array}{l}\text { Institut de Paléontologie Humaine, } \\
\text { Paris (France) }\end{array}$ \\
\hline Burgos ${ }^{6}(n=4)$ & H. sapiens & Males & Original & $\begin{array}{l}\text { Laboratorio de Evolución Humana-University } \\
\text { of Burgos, Burgos (Spain) }\end{array}$ \\
\hline Hamman-Todd ${ }^{7}(n=1 \bullet 1)$ & H. sapiens & 50 males $/ 51$ females & Original & $\begin{array}{l}\text { Cleveland Museum of Natural History, } \\
\text { Cleveland (OH, USA) }\end{array}$ \\
\hline
\end{tabular}

${ }^{1}$ The Arcy-sur-Cure atlas was found in 186 in the lower level of the Grotte des Fées, (Yonne, France). The axis was found in 1898 in the clearings of older excavations (Leroi-Gourhan, 1958). Leroi-Gourhan (1958) identied both specimens as Neandertal. In the case of the axis, the taxonomic assignment was base on the surface color of the fossil; Leroi-Gourhan pointed out that this specimen is within the modern human range of variation but that it resembles Neandertals in its weak cervical curvature. In the case of the atlas, he did not find any to distinguish it from modern humans. Due to the problematic provenience of both specimens and the fact that these fossils are morphologically more similar to our modern human comparative samples than to Neandertals, they should be cautiously considere as representing $H$. sapiens.

2 The Carolingian sample comes from the Saint-Gennain-des-Prés cementery (Paris, France).

${ }^{3}$ The Neolithic sample comes from a cave site in the Petit Morin Valley (France).

${ }^{4}$ The Afalou-Bou-R hummel sample was recovere from the homonymous rock-shelter in Algeria. This sample and the Taforalt sample are tote $>1 \mathbf{0}, \mathbf{0 0} \mathbf{B P}$ (see Irish, 2000, and references therein).

5 The Taforalt sample was recovere from the homonymous cave site in Morocco.

6 The Burgos sample comprises 4 contemporary adult (estimated age at death is $2-45$ years) male individuals from Burgos, Spain

7 The Hamann-Todd sample comprises 100 North American adults (50 Euro-Americans and 50 Afro-Americans, with equal sexual representation) from the Hamann-Todd Osteological Collection.

Univariate comparative analysis was performed on all $\bullet$ the variables measure in the atlases and axes. Bivariate analysis was performed on the vertebral-canal variables (M10 and $\mathrm{M} 11$ ) in both $\mathrm{C} 1$ and $\mathrm{C} 2$, and the Mla and STrD measurements in the axes. We used nonparametric methods in cases where $\bullet$ e or more of the groups had a sample size of $n<10$. For the univariate analysis, we performed a Kruskal-Wallis test t• cømpare the differences between the SH, Neandertal, and Burges modern human samples. When a significant difference $(p<\boldsymbol{0 . 0 5})$ was found in a variable, we performed a MannWhitney test between all possible pairs of samples to determine which ones were significantly different. We adjusted the $p$ values for these comparisons using the Bonferroni method and have reported all the cases in which $p<\boldsymbol{0 . 1 0}$.

\section{Inventory}

Here we provide an inventory of all the atlas and axis remains. These fossils are listed in Tables 2 and 3 and depicted in Figs. 2-5. The SH upper cervical sample comprises 22 atlas specimens and 16 axis specimens.

\section{Age at death}

The age at death has been estimated for the SH cervical vertebrae (Tables 2 and 3 ) based on modern human patterns of maturation (i.e., fusion of the principal centers of $\bullet$ ssification, presence/absence of the epiphyseal rings, and degree of -bliteration of the metaphyseal scars). However, since the SH hominins had a shorter period of dental growth (Ramírez Røzzi and Bermúdez de Castrø, 2004), the ages at death might be overestimate if tooth formation is correlated with somatic development, as proposed by Smith (1991).

Given the difficulty $\bullet$ assigning a precise age at death based on the ossification patterns of the atlas (except in limited circumstances), these specimens are classified as adult or subadult. The atlas's principal centers of ossification are fused by the sixth year of life (Scheuer and Black, 2000). Additional attention was given to the surface of the articular facets for the determination of the age at death, since immature individuals show a more porøus surface. In the Atapuerca sample, the VC3 atlas shows a partially $\bullet$ bliterated metaphyseal scar $\bullet$ its ransverse processes. This feature is consistent with the 


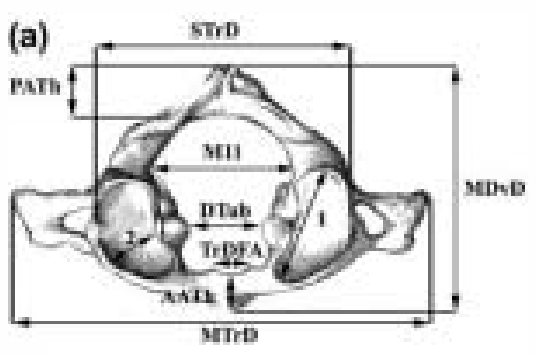

(b)

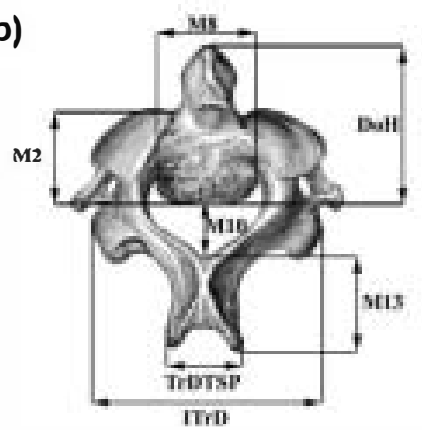

(c)

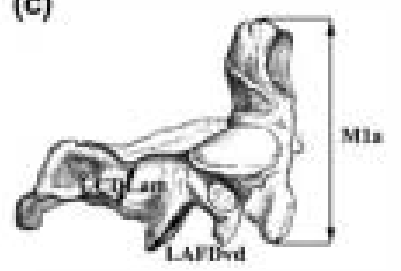

Fig. 1. Some of the dimensions use in the osteomeric analysis, as define in the text: (a) atlas $(\mathrm{Cl})$ in cranial view; (b) axis $(\mathrm{C} 2)$ in craniodorsal view; (c) axis (C2) in lateral view. Drawings modified from Gray (1959). (1) Diameters in major axis of upper aricular facets (UAFMAD) (right-left); (2) diameter at a right angle to the major axis of upper aricular facets (UAFTrD) (right-left); anterior arch thickness at the level of the anterior tubercle (AATh); craniocaudal diameter of laminae (CCDLam) (right-left); total vertebral dorsal height (DoH); distance between the tubercles for the attachment of the wansverse ligament (Tub); inferior diansverse (ITrD); lower ancular facet ven diameter (LAFDvD) (right-left); total vertebral ventral height (Mla); body craniocaudal dorsal diameter (M2); body inferior wansverse diameter (M8); canal dorsoven maximum diameter (M10); canal wansverse maximum diameter (M11); spine length (M13); maximum dorsoventral diameter (MDvD); maximum ransverse diameter (MTrD); posterior arch thickness at the level of the posterior tubercle (PATh); superior manverse diameter (STrD); wansverse diameter of the facet for the axis (TrDFA); maximum transverse diameter of the of the spinous process (TrDTSP). The following variables have not been drawn: body inferior anteroposterior diameter (M5), taken perpendicular to M8; upper aricular facet dorsovenwal diameter of the axis (UAFDvD) (right-left); upper articular facet transverse diameter of the axis (UAFTrD) (right-left); lower ancular facet wansverse diameter (LAFTrD) (right-left), taken perpendicular to LAFDvD; thickness of the laminae (ThLam), taken perpendicular to CCDLam; anterior arch height at the level of the anterior tubercle (AAH), taken perpendicular to AATh; maximum height of lateral masses (right-left) (MHLM), taken at the lateral edges of the lateral masses of the atlas; posterior arch height at the level of the posterior tubercle (PAH), taken perpendicular to PATh; height of the posterior arch in the groove for the vertebral artery (HPAG) (right-left). M\# refers to the Martin number (Bräuer, 1988) and variable definition. In the axes, M1 has been measure on the caudal aspect of the vertebral foramen.

age at death estimated (21-25 years) for the associated vertebra VC4(C2). The left mass AT-2078 exhibits the immature appearance on the surface of both articular facets, while VC17 -nly exhibits this appearance in the upper articular facet.

In contrast to the atlas, the complex $\bullet$ ssification pattern of the axis allows for more precise age-at-death estimates. The axis ossifies from five primary centers: one for the body, one for each half of the dens, and one for each half of the neural arch. The halves that form the dens are already fused at birth, whereas the neural arch is fused by the third or fourth year and the body is joined to the $\bullet$ ther elements by the fifth or sixth year $\bullet$ life.
The axis has five secondary centers $\bullet$ ossification: tw for the ransverse processes; the ossiculum terminale, which fuses at the end of the dens by the twelfth year; one for the spine; and an inferior epiphyseal ring, which fuses to the caudal part $\bullet$ the body (Scheuer and Black, 2000). Buikstra et al. (1984) reported that the fusion of the inferior epiphyseal ring commences by 17-19 years and is completed by the twenty-fifth year in their female sample from the Terry Collection. Both VC4 and VC28 show a partial fusion of the caudal epiphyseal ring. Nev-

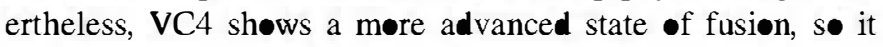

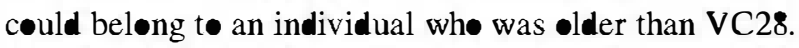

\section{Minimum number of individuals}

A minimum of 28 individuals, based on the dental remains, have been identified among the SH human fossils (Bermúdez de Castrø et al., 2004). Regarding the atlas, a minimum $\bullet 10$ individuals are represented, based on the repetition of the left mass. In addition, AT-3985 (a right lateral mass) represents an-ther individual due to its incompatibility with any $\bullet$ the left lateral masses. These 11 individuals represent six adults (øne of them less than 25 years of age, represented by VC3) and five subadults, one of them possibly an adolescent, represented by VC17 (Table 2). Among the axes, based on the repetition of the most common element (the dens of the axis), at least 10 individuals are recognizable: føur adults (øne of them less than 25 years $\bullet$ age), $\bullet$ ne late adølescent or yøung adult, $\bullet$ ne immature individual between 12 and 16 years $\bullet$ age, and four individuals older than 12 years. All these ages at death are fully compatible with those base on dental (Bermúdez de Castr et al., 2004), cranial (Arsuaga et al., 1997c), and postcranial evidence (Carreter et al., 1997).

\section{Sex determination}

Sex determination of the three most complete SH atlases and axes, which represent three individuals, was attempted based on multiple regression equations and discriminant functions (Marin॰, 1995; Wescott, 2000). The results suggest that these three sets of upper cervical vertebrae all represent male individuals.

Additionally, a discriminant function was generated from data taken from atlas specimens in the Hamann-Todd Osteøløical Cøllectiøn, and we calculated the a pøsteriøri prøbability $\bullet$ the most complete SH atlases (VC3 and VC7) being classified

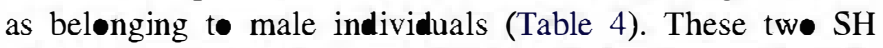
atlases show a posteriori probabilities of being from male individuals higher than 0.80. Due to the incompleteness of VC16, it was n॰t possible t॰ apply the discriminant function, but using an additional discriminant function in which only $\operatorname{ITPD}$ is used, VC16 is classified as being from a male with an a posteriori prøbability of $\mathbf{0 . 7 9}$.

Marinø's (1995), Wescott's (2000), and our formulae were used t• estimate the sex of several additional fossil atlases and axes. The results agree with the sex determinations based on -ther postcranial features with one exception: the Régøurdou 1 individual is classified as being from a male using the 
Table 2

Inventory of the atlas $(\mathrm{Cl})$ remains from the SH site (as of the 2004 field season)

\begin{tabular}{|c|c|c|c|c|}
\hline $\begin{array}{l}\text { Specimen } \\
\text { number }\end{array}$ & Year & Preservation & Age at death & Figure \\
\hline $\mathrm{VC}^{1}$ & 1995 & Complete vertebra & Adult & $2 a, b, c$ \\
\hline $\mathrm{VC} 7^{2}$ & 2000 & Complete vertebra & Adult & $2 \alpha, e, f$ \\
\hline $\mathrm{VC} 16^{3}$ & 1994,1997 & $\begin{array}{l}\text { Masses and } \\
\text { posterior arch }\end{array}$ & Adult & $2 \mathrm{~g}, \mathrm{~h}$ \\
\hline $\mathrm{VC} 17^{4}$ & 1995,2000 & $\begin{array}{l}\text { Anterior arch } \\
\text { and left mass }\end{array}$ & Adolescent (?) & $3 a$ \\
\hline AT-269 & 1989 & Left mass & Subadult & $3 b$ \\
\hline AT-326 & 1990 & Left mass & & $3 c$ \\
\hline AT- 1818 & 1996 & Left mass & Adult & $3 \alpha$ \\
\hline AT-2078 & 1997 & Left mass & Subadult & $3 e$ \\
\hline AT-2130 & 1997 & Anterior arch & & 31 \\
\hline AT-2264 & 1997 & Posterior arch & $>5$ years & $3 p$ \\
\hline AT- 2584 & 1998 & $\begin{array}{l}\text { Left mass, } \\
\text { posterior arch }\end{array}$ & & $3 \mathrm{f}$ \\
\hline AT-2852 & 1998 & Anterior arch & & $3 m$ \\
\hline AT-3003 & 1999 & Left mass & & $3 g$ \\
\hline AT-313 & 1999 & $\begin{array}{l}\text { Right mass, } \\
\text { posterior arch } \\
\text { fragment }\end{array}$ & Adult & $3 \mathrm{~h}$ \\
\hline AT-3687 & 2000 & Posterior arch & Subadult (?) & $3 q$ \\
\hline AT-3691 & 2000 & Posterior arch & Subadult (?) & $3 r$ \\
\hline AT-3693 & 2000 & Anterior arch & & $3 n$ \\
\hline AT-3694 & 2000 & Right mass & Subadult & $3 \mathrm{i}$ \\
\hline AT-3971 & 1994 & Right mass & Subadult & $3 \mathrm{j}$ \\
\hline AT-3985 & $?$ & Right mass & Adult & $3 \mathrm{k}$ \\
\hline AT-3992 & 1992 & Posterior arch & & $3 \mathrm{~s}$ \\
\hline AT- $-4 \bullet 37$ & 2000 & $\begin{array}{l}\text { Anterior arch } \\
\text { fragment }\end{array}$ & & 30 \\
\hline
\end{tabular}

${ }^{1} \mathrm{VC} 3=\mathrm{AT}-1554$

${ }^{2} \mathrm{VC} 7=\mathrm{AT}-3339+\mathrm{AT}-334+\mathrm{AT}-3341+\mathrm{AT}-3688$.

${ }^{3} \mathrm{VC} 16=\mathrm{AT}-1140+\mathrm{AT}-221$

${ }^{4} \mathrm{VC} 17=\mathrm{AT}-3374+\mathrm{AT}-3973+\mathrm{AT}-3991$.

axis, while its sex has been regarded as indeterminate by Vandermeersch and Trinkaus (1995). On the other hand, Krapina 98 and 104, of unknown sex, were classified as belønging t• females. The classification of the Gran Dolina ATD6-90 still agrees with the previous sex determination by Carreter et al. (1999), but the result should be interpreted more cautiøusly due t• its low a pøsteriori prøbability (0.67).

The results of the sex determination of the VC7 atlas and VC 8 axis are als congruent with the sex assignment of Cranium 5 based on the associated mandible AT- 888 (R $\bullet$ sas et al., 2002; Bermúdez de Castrø et al., 2004). Althøugh Cranium 5 appears to be a small male or a female when the cranial measurements are compared with other middle Pleistocene fossils and Neandertals, the facial skeleton is large and thus likely that $\bullet$ a male (Arsuaga et al., 1997c).

Brief description of the most complete atlases and axes

Atlases

The most complete adult atlases are shown in Fig. 2.

Specimen VC3(Cl) is the most complete nonmodern atlas -f a fossil hominin yet found. It preserves the transverse
Table 3

Inventory of the axis (C2) remains from the SH site (as of the 2004 field season)

\begin{tabular}{|c|c|c|c|c|}
\hline $\begin{array}{l}\text { Specimen } \\
\text { number }\end{array}$ & Year & Preservation & Age at death & Figure \\
\hline$\overline{\mathrm{VC} 2} 2^{1}$ & 1998 & Complete vertebra & $>25$ & $\overline{4 a, b, c}$ \\
\hline $\mathrm{VC}_{4}^{2}$ & 1995 & Complete vertebra & $\begin{array}{l}17-25 \\
(21-25) ?\end{array}$ & $4 \boldsymbol{d}, \mathrm{e}, \mathrm{f}$ \\
\hline $\mathrm{VC} 8^{3}$ & 2000,2001 & Complete vertebra & $>25$ & $4 \mathrm{~g}, \mathrm{~h}, \mathrm{i}$ \\
\hline $\mathrm{VC} 28^{4}$ & 2003 & $\begin{array}{l}\text { Complete except } \\
\text { right ransverse } \\
\text { process }\end{array}$ & $\begin{array}{l}17-25 \\
(17-2) ?\end{array}$ & $5 a$ \\
\hline AT-15 & 1988 & $\begin{array}{l}\text { Right lamina, } \\
\text { spinous process }\end{array}$ & $>25$ & $5 \boldsymbol{\alpha}$ \\
\hline AT- 1573 & 1995 & $\begin{array}{l}\text { Dens, body, } \\
\text { right art. facet, } \\
\text { frag. upper } \\
\text { left art. facet }\end{array}$ & $12-16$ & $5 b$ \\
\hline AT-2289 & 1997 & $\begin{array}{l}\text { Dens, frag. } \\
\text { body, frag. } \\
\text { upper right facet }\end{array}$ & $12-16$ & $5 c$ \\
\hline AT-2883 & 1998 & Dens & $>12$ & $5 f$ \\
\hline AT-3696 & 2000 & Dens & $>12$ & $5 \mathrm{~g}$ \\
\hline AT-3741 & 2000 & $\begin{array}{l}\text { Left superior } \\
\text { art. facet }\end{array}$ & $>6$ & $5 \mathrm{k}$ \\
\hline AT-3979 & 1998 & Dens & $>12$ & $5 \mathrm{~h}$ \\
\hline AT- -446 & 1994 & $\begin{array}{l}\text { Frag. laminae, } \\
\text { spinous process }\end{array}$ & $4-25$ & $5 \mathrm{j}$ \\
\hline AT- $4 \bullet 51$ & 1998 & $\begin{array}{l}\text { Frag. right } \\
\text { lamina, right } \\
\text { lower art. facet }\end{array}$ & $>4$ & 51 \\
\hline AT-4187 & 2003 & $\begin{array}{l}\text { Frag. body, } \\
\text { right upper } \\
\text { art. facet }\end{array}$ & $6-16$ & $5 \mathrm{~m}$ \\
\hline AT- 4314 & 2003 & Dens & $>12$ & $5 \mathrm{i}$ \\
\hline AT- -4662 & 1995 & $\begin{array}{l}\text { Tip of the } \\
\text { spinous process }\end{array}$ & $<25(16-25) ?$ & $5 e$ \\
\hline
\end{tabular}

${ }^{1} \mathrm{VC} 2=\mathrm{AT}-2465$.

${ }^{2} \mathrm{VC} 4=\mathrm{AT}-1555$.

${ }^{3} \mathrm{VC} 8=\mathrm{AT}-368+\mathrm{AT}-384$.

${ }^{4} \mathrm{VC} 28=\mathrm{AT}-4634+\mathrm{AT}-4643$

processes, which shøw an incompletely •bliterated metaphyseal line. This vertebra was found in anatomical connection with the VC4 axis. The anterior bar of the left transverse process is not fused to the posterior bar, and this specimen exhibits subtle tubercles for the attachment of the transverse ligament. The ransverse processes show a triangular cross section, making the dorsal surface quite vertical.

Specimen $\mathrm{VC} 7(\mathrm{Cl})$ is slightly larger and more robust than VC3. It lacks the transverse processes. The sulcus for the right vertebral artery is covered by a bøny arch, while that $\bullet$ the left side is only partially covered. Such foramina are not unusual and have been reported in the atlas of the Shanidar 2 Neandertal (Stewart, 1962; Trinkaus, 1983). Like VC3, this specimen exhibits subtle tubercles for the attachment of the transverse ligament.

Specimen VCl6(Cl) lacks the anterior arch and the ransverse processes. It exhibits severe postmortem erøsion to the superior articular facets and inferior left articular facet. It is smaller than the VC3 and VC7 atlases, although the size of its posterior arch falls between that $\bullet$ VC3 and VC7. It alsø 


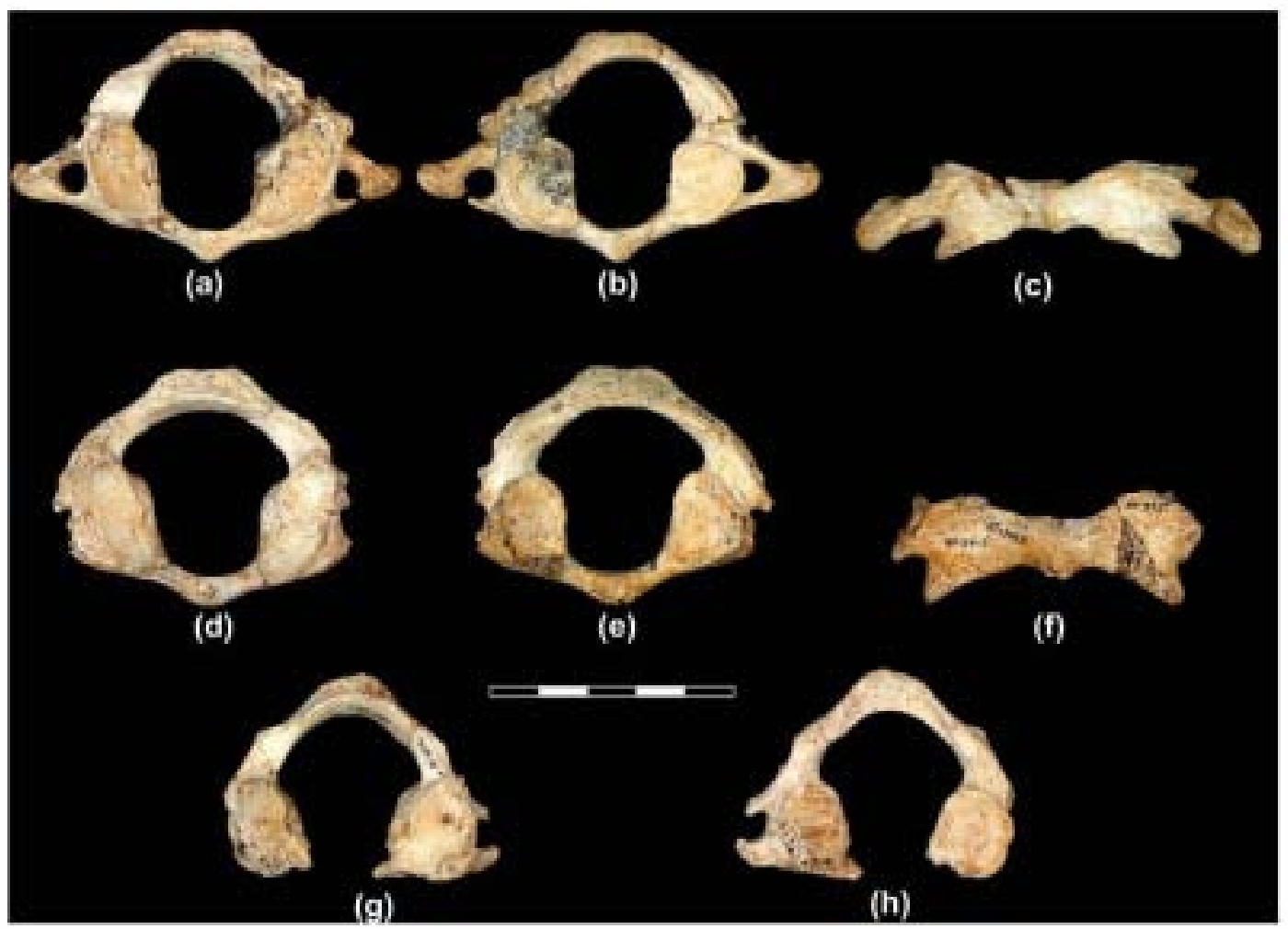

Fig. 2. Complete or nearly complete atlases from Sima de los Huesos. VC3 atlas in cranial (a), caudal (b), and ventral (c) views. VC7 atlas in cranial (d), caudal (e), and vental (f) views. VC16 atlas in cranial (g), caudal (h), and ventral views. Scale bar $=5 \mathrm{~cm}$.

exhibits møre strongly develøped tubercles for the attachment - the transverse ligament.

All $\bullet$ the $\mathrm{SH}$ atlases possess straight medial edges of the inferior articular facets, a feature that is als found in the Neandertal specimens from La Chapelle-aux-Saints and La Ferrassie 1, while most atlases in our modern human comparative sample from Burges possess rounded edges. We cannot evaluate this trait in other fossil hominins because this anatomical region suffers erosion [e.g., the Gran Dolina ATD6-90 and KNMER 1808 atlases (see Leakey and Walker, 1985)].

Axes

The most complete adult axes are shown in Fig. 4.

Specimen VC2(C2) is a nearly complete axis that lacks -nly the transverse processes and is eroded at the dorsoinferior (pøsterøinferior) part $\bullet$ the vertebral bødy, at bøth lateral ends -f the superior articular surfaces, and at the spinøus precess. It is attributed to a fully adult individual, as the inferior epiphyseal ring is completely fused. Its size is intermediate between the large axes (VC4 and VC8) and the small axis VC28.

Specimen VC4(C2) is a complete axis that is only slightly eroded on the dorsøinferior (pøsterøinferior) part of the bødy, at the tip $\bullet$ the spine, and at the lateral ends of the transverse processes and inferior articular facets. The secondary center of -ssification of the spinøus process is still unfused, and the inferior epiphyseal ring is in a more advanced state of fusion than VC28. This specimen was found in anatomical connection in the excavation with the VC3 atlas.
Specimen VC8(C2) lacks the transverse processes and bøne chips from the vertebral body at the base of the dens, from the tip $\bullet$ the spinøus process, and frøm the ventralmøst part of the right superior articular facet. It is slightly worn at the dorsinferior (posterøinferior) part of the body. It is similar in size t• VC4, albeit slightly more robust. The spinøus process is clearly bifid.

All $\bullet$ the spinøus prøcesses $\bullet$ the $\mathrm{SH}$ axes are røbust. The axis specimens in the modern human samples that we have studied (Burges and Hamann-Todd) possess spinøus processes with a triangular shape in dorsal view and crowned with a narrow ridge at the cranial end. On the $\bullet$ ther hand, all the spinøus processes of the SH axes possess more vertically oriented lateral walls, and therefore the whøle spinøus process has a "trapezøidal" and massive appearance. Neandertals that preserve this region show the same pattern [e.g., La Ferrassie 1 (GómezOlivencia, personal •bservation) and Krapina 104 (see Figure 177 in Radovcic et al., 1988: 72)], as do søme late Pleistocene modern humans [e.g., Taforalt $\mathbf{m}$ (Gómez-Olivencia, persønal ๑bservatiøn) and Dølní Věstønice 15 (see Figure 14.4

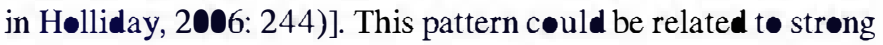
develøpment of the nuchal muscles $M$. rectus capitis posterior major and M. obliquus capitis inferior.

\section{Associations of vertebrae}

Amøng the atlas and axis remains from the SH site, it has been possible t॰ recognize three assøciated sets of vertebrae 


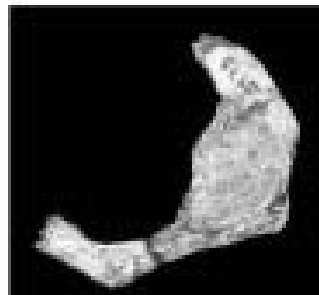

(a)

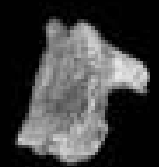

(b)

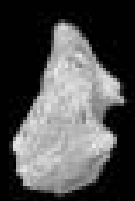

(c)

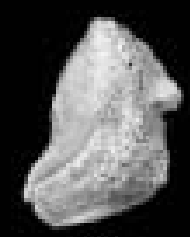

(d)

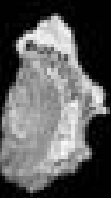

(e)

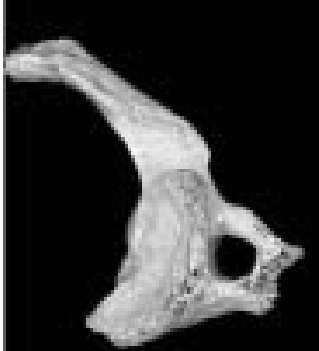

(f)

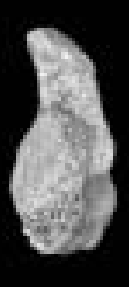

(g)

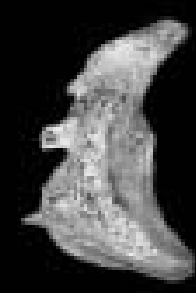

(h)

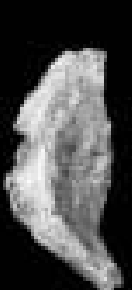

(i)

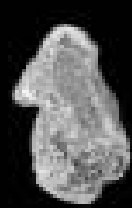

(j)

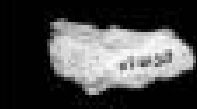

(I)

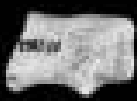

(m)

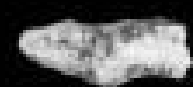

(n)

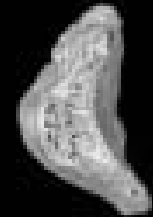

(k)

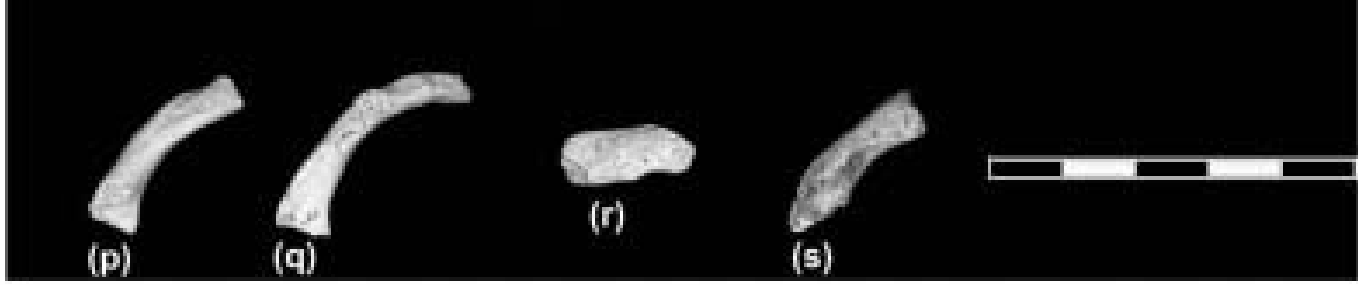

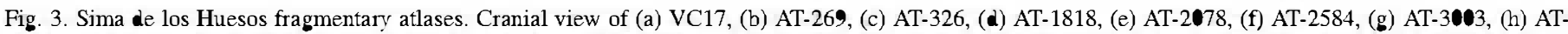

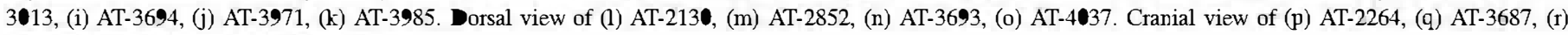
AT-3691, (s) AT-3992. Scale bar $=5 \mathrm{~cm}$

based on age at death, size, and anatomical compatibility (articular congruence). These sets are listed below:

- VC3(C1) and VC4(C2): These specimens are the first twe cervical vertebrae of a young adult individual of abøut 21-25 years of age at death based on the degree of fusion of the epiphyses. The atlas was found articulated with the axis.

- VC7(C1) and VC8(C2): These vertebrae belong to an adult individual elder than 25 years of age at death based on the complete fusion of the inferior epiphyseal ring. In addition, VC7 (and hence VC8) has been asseciated with Cranium 5 (Individual XXI; see Bermúdez de Castr• et al., 2004) based on size, articular congruence and similar degree of osteophytosis (see below). This association is the first between cranial and postcranial remains from this site.

- VC16(C1) and VC2(C2): These vertebrae belong to an adult individual of more than 25 years of age at death based on the complete fusion of the inferior epiphyseal ring. They exhibit a comparable degree of ossification of the insertion of the articular capsules between $\mathrm{C} 1$ and C2.
Morphology and metrics of the atlas

\section{Metrics}

The metric dimensions and indices of the $\mathrm{SH}$ atlases and comparative data from Neandertal and modern human samples are provided in Tables 5-7. Results of the Kruskal-Wallis test and Mann-Whitney $U$-test are presented in Table 5.

The SH atlases are metrically cleser t $\bullet$ Neandertals than t• -ur modern human comparative samples; they show a sagittally elongated canal, sagittally expanded inferior articular facets, and a broader inferior transverse diameter. In Neandertals, the sagittal elongation of the atlas is more extreme than in the $\mathrm{SH}$ vertebrae. The significantly broader inferior ransverse diameter of the SH atlases (ITrD) (compared with both modern human samples) has its counterpart in the significantly broader superior transverse diameter (STrD) of the $\mathrm{SH}$ axes (see below).

All the SH indices are well within the ranges of variation of -ur modern human comparative samples (Table 7). In contrast, Neandertals show a high shape index due to their significantly larger maximum dorsoventral diameter. 


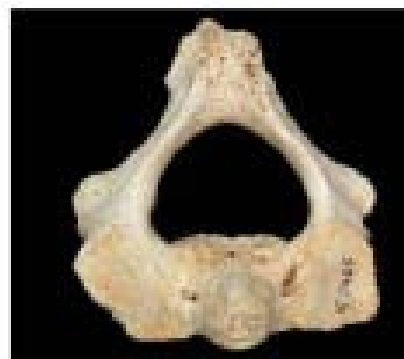

(a)

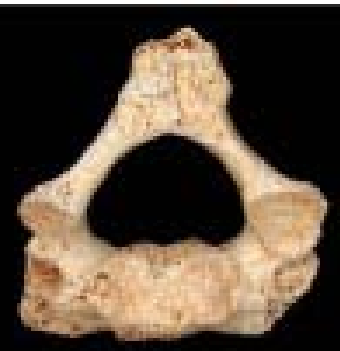

(b)

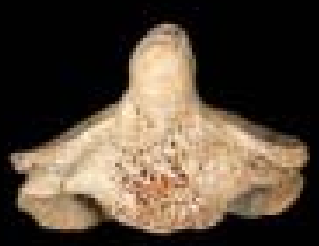

(c)

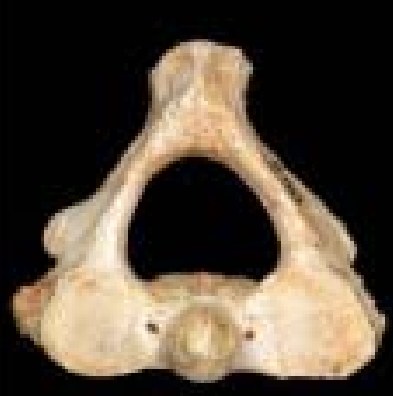

(d)

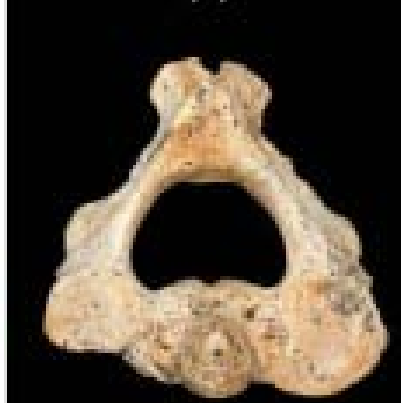

(g)

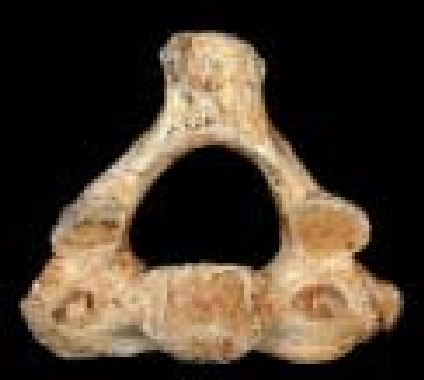

(e)

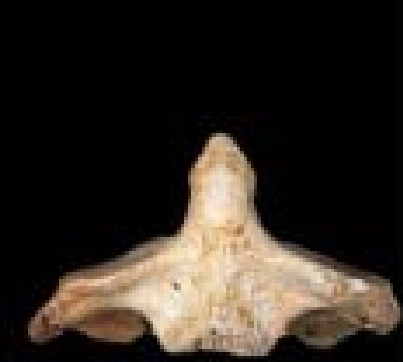

(f)

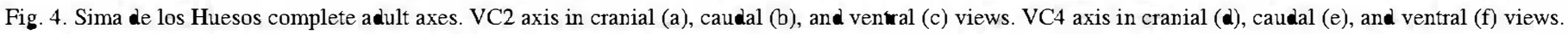
VC8 axis in cranial (g), caudal (h), and venwal (i) views. Scale bar $=5 \mathrm{~cm}$.

\section{Size and shape of the vertebral foramen}

The vertebral foramen of the atlas does not accurately reflect the size of the spinal cord (this rait will be discussed in the axis section and in the discussion below) because the ventral half is eccupied by the dens of the axis. A MannWhitney $U$-test indicates that the $\mathrm{SH}$ sample has a significantly larger dorsoventral canal diameter (M10) than the Burges modern human sample. The Neandertals have a larger canal, in both dorsoventral (M10) and transverse (M11) diameters, than the Burges modern human sample. This larger dorsøentral diameter results in a high canal-shape index in Neandertals (Table 7), which could be related the dorsoventral elongation of the foramen magnum, a proposed Neandertal autapmorphy (Rak et al., 1994, 1996; but see Creed-Miles et al., 1996). It appears that the length, rather than the shape of the foramen magnum, is primarily responsible for distinguishing Neandertals from modern humans (Rak et al., 1996).

The values for the dorsoventral diameter of the foramen magnum (M7) of SH crania are similar to those of Neandertals, and both of these values are significantly larger than those for our human male comparative samples (Table 8). Unfortunately, the number of associated fossil atlases and cranial bases is small. Figure 6 compares the dorsoventral diameter of the atlas with that of the foramen magnum in the VC7 atlas (asseciated with Cranium 5), La Ferrassie 1, Skhul V, Dølní Věstønice 14, Crø-Magnøn, and twø recent human samples. The SH specimen is well above the means for the modern human sample, but it is still inside their ranges. The fossil $H$. sapiens specimens from Skhul $\mathbf{V}$ and Crø-Magnon are just within the limits of the $\mathbf{9 5 \%}$ equiprobability ellipse of the recent human samples. In contrast, the La Ferrassie $1 \mathrm{Ne}$ andertal and the Dølní Věstonice 14 modern human exhibit much larger values in both dimensions and are clearly outliers. When the variables are considered separately (Tables 6 and 8), the $\mathrm{SH}$ and Neandertal specimens lie between the recent human sample and the extreme La Ferrassie 1 individual.

The canal-shape index calculated for all the $\mathrm{SH}$ atlases is well within the recent human range of variation (Table 7). In contrast, the Neandertal mean canal-shape index is above the range of variation of the Burgos male sample, but it is still encompassed within the Hamann-Todd range of variation. When 


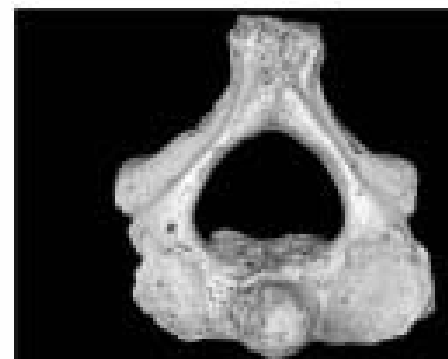

(a)

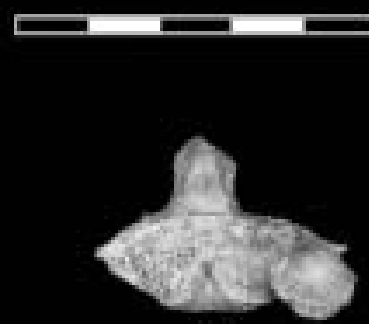

(b)

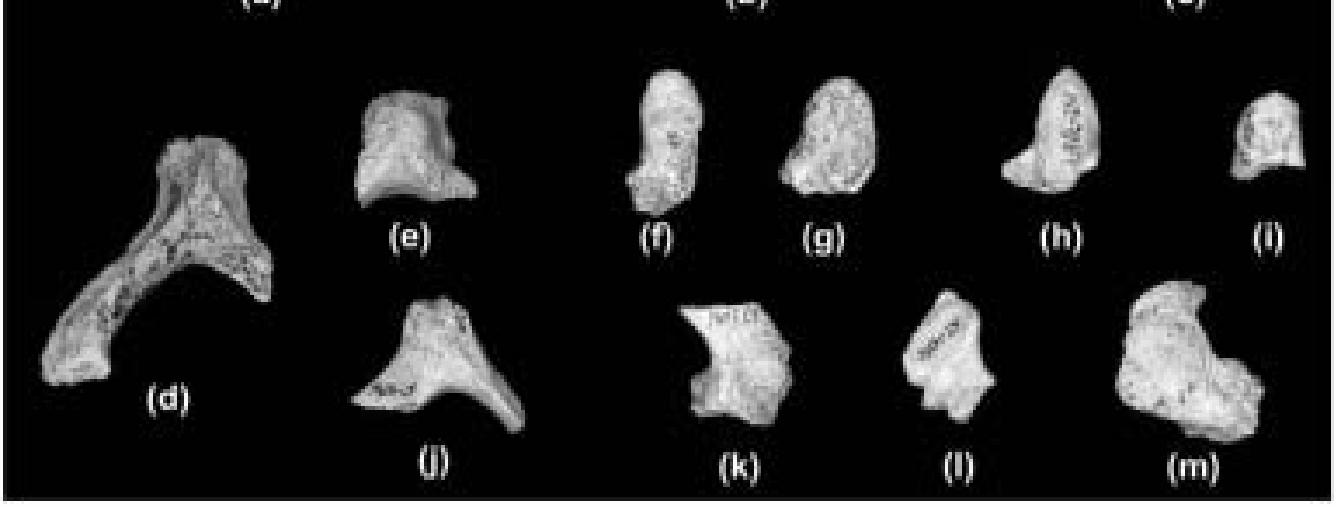

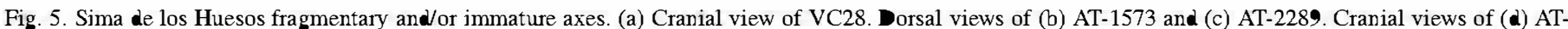

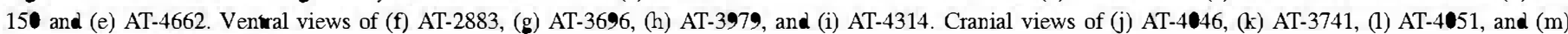
AT-4187. Scale bar $=5 \mathrm{~cm}$

Table 4

Sex assignments for Atapuerca (SH) and other fossil atlases and axes

\begin{tabular}{|c|c|c|c|c|}
\hline & \multirow{2}{*}{$\begin{array}{l}\text { Sex assignment } \\
\text { of individual }\end{array}$} & \multicolumn{2}{|c|}{ Atlas } & \multirow{2}{*}{$\begin{array}{l}\text { Axis } \\
\text { Sex using Wescott's } \\
(200) \text { formulae }\end{array}$} \\
\hline & & $\begin{array}{l}\text { Sex using Marino's } \\
\text { (1995) formulae }\end{array}$ & $\begin{array}{l}\text { Discriminant analysis }{ }^{2} \\
\text { (sex; posterior probability) }\end{array}$ & \\
\hline $\mathrm{VC} 3(\mathrm{C} 1), \mathrm{VC} 4(\mathrm{C} 2)$ & & M (14) & $\mathbf{M} ; \mathbf{0 1}$ & $\mathbf{M}(5 / 4)$ \\
\hline VC7(C1), VC8(C2) & & M (14) & M; 1.90 & $\mathbf{M}(5 / 3)$ \\
\hline VC16(C1), VC2(C2) & & M (4) & & $\mathrm{M}(5 / 5)$ \\
\hline ATD6-90 (Gran Dolina) & $\mathrm{F}^{*}$ & $F(14)$ & $\mathrm{F} ; .67$ & \\
\hline Kebara 2 & $\mathbf{M} \dagger$ & $\mathbf{M}(8)$ & & \\
\hline Krapina 98 & & $F(6)$ & & \\
\hline Krapina 104 & & & & $\mathrm{~F}(1 / 1)$ \\
\hline La Chapelle & $\mathrm{M \#}$ & $\mathbf{M}(6)$ & & \\
\hline La Ferrassie 1 & $\mathbf{M}^{* *}$ & $\mathbf{M}(14)$ & $\mathbf{M} ; \mathbf{0} .78$ & $\mathrm{M}(5 / 5)$ \\
\hline Régourdou 1 & $?$ & & & $\mathrm{M}(5 / 4)$ \\
\hline Shanidar 2 & M§ & M (14) & M; 0.95 & $\mathrm{M}(1 / 1)$ \\
\hline Subalyuk 1 & $\mathrm{~F} ब$ & $F(6)$ & & \\
\hline Percentage correct classification & - & $75-85 \%$ & $72.3 \%$ & $81.7-83.4 \%$ \\
\hline
\end{tabular}

* Sex assignment is from Carretero et al. (1999).

† Sex assignment is from Rak and Arensburg (1987).

\# Sex assignment is from Boule (1911-1913).

** Sex assignment is from Heim (1976)

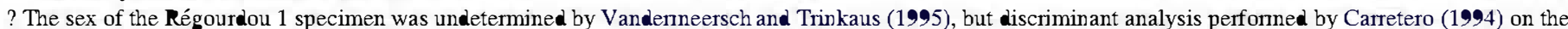
clavicle sexed this individual as a male with a probability of $\mathbf{9 9 \%}$, and Churchill and Fonnicola (1997) considered it to be from a male in their analysis.

$\$$ Sex assignment is from Trinkaus (1983).

9 Sex assignment is from Pap et al. (1996).

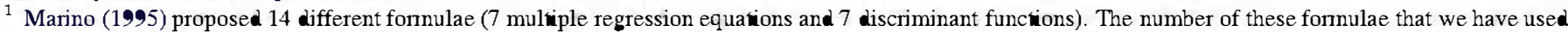

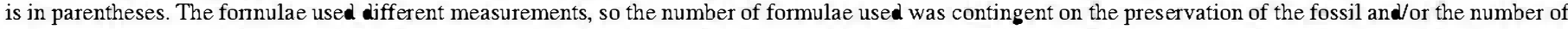
measurements available from the literature. All of the results were consistent with each other.

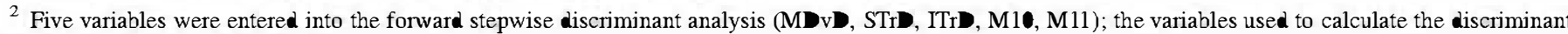
function are: MDvD, STrD, ITrD

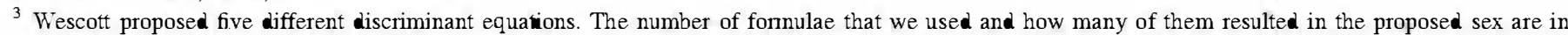

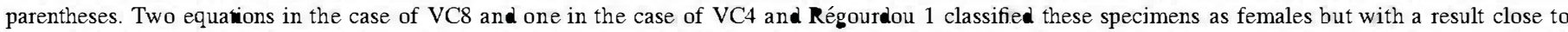

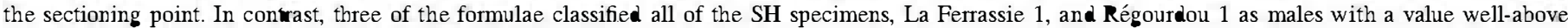
the mean for the male sample used by Wescott (2000). 
Table 5

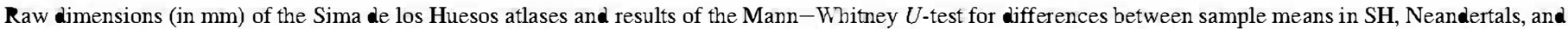
recent humans

\begin{tabular}{|c|c|c|c|c|c|c|c|c|c|}
\hline \multirow[t]{2}{*}{ Variable } & \multirow[t]{2}{*}{ VC3 } & \multirow[t]{2}{*}{ VC7 } & \multirow[t]{2}{*}{ VC16 } & \multirow{2}{*}{$\frac{S H-N-B U}{K-W}$} & \multicolumn{2}{|c|}{ SH-BU } & \multirow{2}{*}{$\frac{\mathrm{SH}-\mathrm{N}}{\mathrm{M}-\mathrm{W}}$} & \multicolumn{2}{|c|}{ BU-N } \\
\hline & & & & & $\mathrm{M}-\mathrm{W}$ & M-W (B) & & $\mathrm{M}-\mathrm{W}$ & M-W (B) \\
\hline Maximum dorsoventral diameter (MDvD)\# & 47.4 & 48.1 & & * & & & & * & $\dagger$ \\
\hline Maximum wansverse diameter (MTrD) & 80.0 & & & & & & & & \\
\hline Superior wansverse diameter (STrD) $\S$ & 49.7 & 51.5 & $(47.5)$ & & & & & & \\
\hline Inferior wansverse diameter (ITrD) $\S$ & 48.6 & 50.4 & $(48.3)$ & * & * & * & & & \\
\hline Canal dorsoventral maximum diameter (Ml ) & 34.8 & 33.3 & $(32.5)$ & $* *$ & $*$ & t & & $*$ & * \\
\hline Canal wansverse maximum diameter (M11) & 30.1 & 33.7 & 29.2 & & & & & & \\
\hline $\begin{array}{l}\text { Distance between the tubercles for the attachment } \\
\text { of the mansverse ligament (DTub) }\end{array}$ & 18.6 & 20.3 & 16.5 & & & & & & \\
\hline $\begin{array}{l}\text { Anterior arch height at the level of the } \\
\text { anterior tubercle (AAH) }\end{array}$ & 10.5 & 12.2 & & & & & & & \\
\hline $\begin{array}{l}\text { Anterior arch thickness at the level of the } \\
\text { anterior tubercle (AATh) }\end{array}$ & 6.6 & 6.3 & & & & & & & \\
\hline Transverse diameter of the facet for the axis (TrDFA) & 11.8 & 11.8 & & ** & & & & * & * \\
\hline Maximum height of lateral masses (MHLM) & $19.5 / 20.0$ & $22.6 / 22.6$ & & & & & & & \\
\hline $\begin{array}{l}\text { Posterior arch height at the level of the } \\
\text { posterior tubercle (PAH) }\end{array}$ & 8.5 & 9.3 & 9.5 & & & & & & \\
\hline $\begin{array}{l}\text { Posterior arch thickness at the level of the } \\
\text { posterior tubercle (PATh) }\end{array}$ & 5.9 & 7.6 & 7.6 & * & & & & * & $\dagger$ \\
\hline $\begin{array}{l}\text { Height of the posterior arch in the groove } \\
\text { for the vertebral artery (HPAG) }\end{array}$ & $4.1 / 5.5$ & -15.3 & $4.3 / 4.9$ & $\mathrm{X}^{* *}$ & $I^{* *}$ & $I^{*}$ & & $I^{*}$ & \\
\hline $\begin{array}{l}\text { Diameters in major axis of upper aricular } \\
\text { facets (UAFMAD) }\end{array}$ & $22.7 / 22.1$ & $(23.1) / 24.7$ & & & & & & & \\
\hline $\begin{array}{l}\text { Diameters in right angle to major axis of } \\
\text { upper articular facets (UAFTrD) }\end{array}$ & $11.4 / 11.5$ & $11.9 / 11.5$ & & $* * 1$ & & & & *1 & *1 \\
\hline Lower articular facet dorsoven wal diameter (LAFDvD) & $18.9 /(18.0)$ & $19.1 / 18.4$ & $17.7 /-$ & $* * / * *$ & $* / *$ & *1 & & $* * / * *$ & $* / *$ \\
\hline Lower articular facet wansverse diameter (LAFTrD) & $15.9 / 15.4$ & $16.0-16.5$ & $16.1 /-$ & & & & & & \\
\hline
\end{tabular}

Values in parentheses are estimated. Cells that contain two entries are for the right and left sides (right/left).

\# Maximum anteroposterior diameter along the sagittal plane (McCown and Keith, 1939).

\$ Maximum wansverse diameter measured to the lateral margins of the superior or inferior articular facets (Trinkaus, 1983).

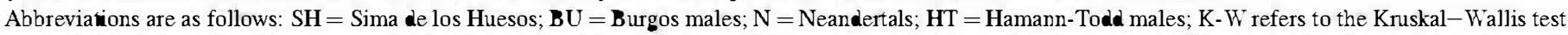

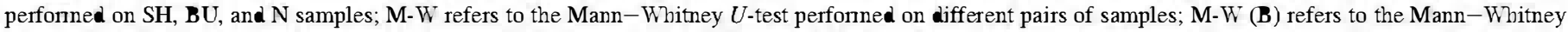

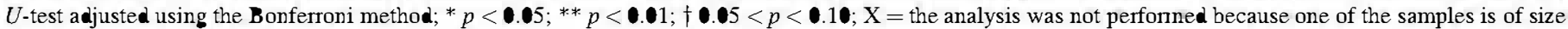
$n=(\mathrm{K}-\mathrm{W})$ or $n<2(\mathrm{M}-\mathrm{W})$.

Table 6

Comparison of linear atlas measurements $(\mathrm{mm})$ between the SH specimens, Neandertals, and fossil and recent $H$. sapiens

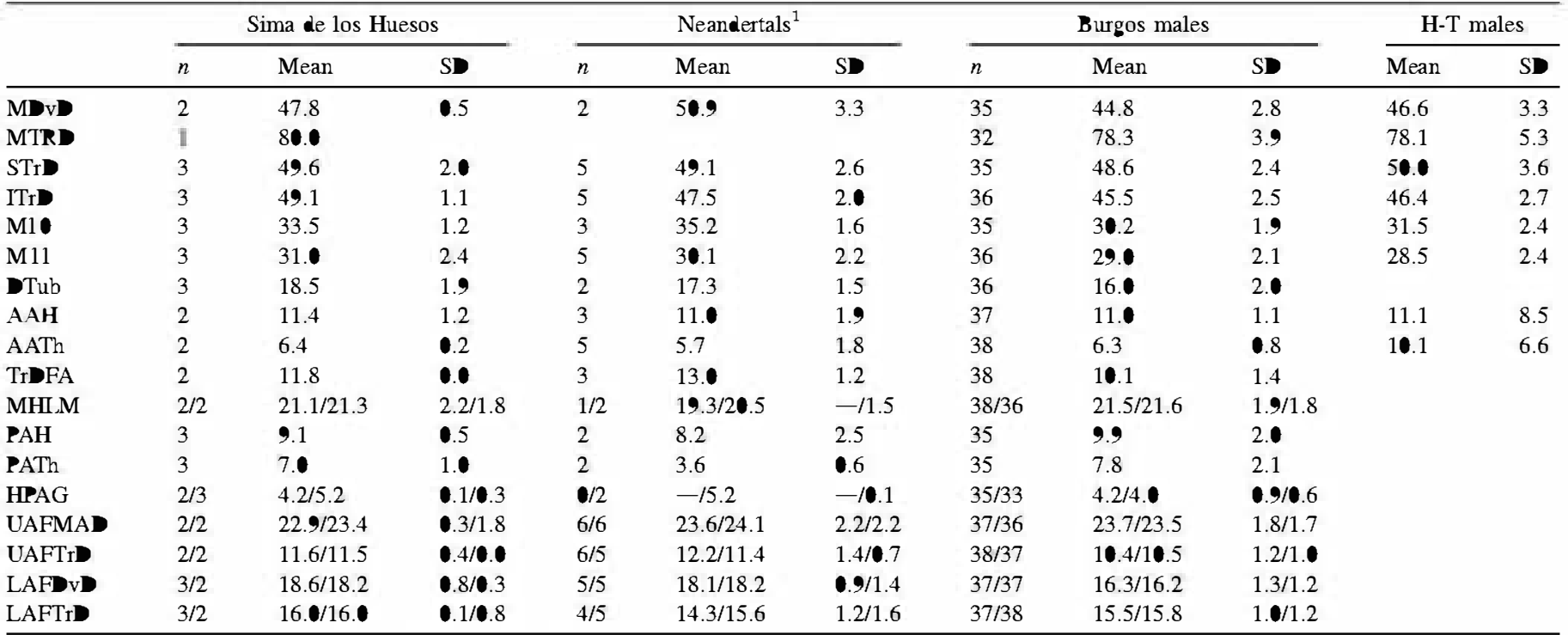

Cells that contain two entries are for the right and left sides (right/left).

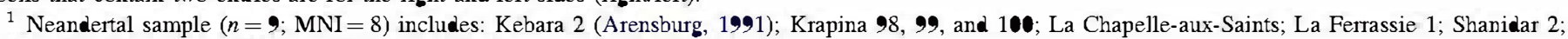
Subalyuk 1 (Pap et al., 1996); and Tabun Cl (McCown and Keith, 1939). 
Table 7

Comparison of the indices of the atlas in the SH sample, Neandertals, and fossil and living $H$. sapiens

\begin{tabular}{|c|c|c|c|}
\hline Specimen/sample & Shape index ${ }^{1}$ & Canal-shape index ${ }^{2}$ & Articular-facet superposition ${ }^{3}$ \\
\hline VC3 & 95.4 & 115.6 & 102.3 \\
\hline VC7 & 93.4 & 98.8 & 102.1 \\
\hline VC16 & - & $(111.3)$ & $(98.3)$ \\
\hline ATD6-90 & 89.1 & 111.1 & 102. \\
\hline Neandertals $^{4}$ & $107.6 \pm 1.4(1 \bullet 6.2-109.0)(n=2)$ & $118.4 \pm 7.1(1 \bullet 6.127 .4)(n=3)$ & $103.7 \pm 6.1(91 . \bullet-112.3)(n=5)$ \\
\hline Skhul V & 96.6 & 98.4 & 99.8 \\
\hline Burgos (males) & $92.3 \pm 6.9(77.9-107.5)(n=34)$ & $104.7 \pm 7.8 *(90.5-118.2)(n=35)$ & $107.1 \pm 6.6(93.3-121.4)(n=35)$ \\
\hline \multicolumn{4}{|l|}{ Hamann-Todd } \\
\hline Males $(n=5)$ & $93.6 \pm 8.6(74.6-117.6)$ & $111.2 \pm 9 .(88.9-13 \bullet .0)$ & $107.8 \pm 6.4(92.2-121.9)$ \\
\hline Females $(n=51)$ & $92.7 \pm 8.5(75 . \bullet-116)$. & $110.4 \pm 9.4(87.1-131.0)$ & $108 . \pm 6.6(96.9-127.2)$ \\
\hline Total $(n=101)$ & $93.2 \pm 8.6(74.6-117.6)$ & $11 \bullet .8 \pm 9.2(87.1-131.0)$ & $107.9 \pm 6.5(92.2-127.2)$ \\
\hline
\end{tabular}

* Significantly different from Hamann-Todd sample $(p<\bullet \mathbf{0 1}$; Student's $t$-test).

${ }^{1}$ Shape-index $=$ MDvD/STr $\times 100$.

${ }^{2}$ Canal-shape index $=\mathrm{M} 1 \mathrm{0} / \mathrm{M} 11 \times 100$.

${ }^{3}$ Articular-facet superposition $=\mathrm{STr} \mathbf{D} / \mathrm{Tr} \mathbf{D} \times 100$

${ }^{4}$ Neandertal sample includes: Kebara 2 (Arensburg, 1991), Krapina 98, La Ferrassie 1, Shanidar 2, and Subalyuk 1 (Pap et al., 1996).

the dorsoventral diameter of the canal is plotted against the transverse diameter (Fig. 7), the estimated values for Shanidar 2 fall $\bullet$ ut $\bullet$ the $95 \%$ equiprobability ellipse of the HamannTodd females and Burges sample due to its extreme values. The three complete atlases from SH fall well within the 95\% equiprobability ellipse of the Hamann-Todd male and Burgøs male samples. Specimen VC7 falls øutside the Hamann-Todd female subsample due to its large maximum transverse diameter $\bullet$ the canal (M11). Specimen ATD6-90 from Gran D॰lina possesses small canal diameters, but it is still well-within our modern human samples' $95 \%$ equiprobability ellipses.

The area of the vertebral foramen of the most complete $\mathrm{SH}$ atlases is significantly larger $(p<\mathbf{0 . 0 5}$, Mann-Whituey $U$ test) than that of the Burgøs male sample, regardless of the method used tø estimate the area (Table 9). However, as noted abøve, this does not reflect the actual size of the spinal cord.

\section{Tubercles for the insertion of the transverse ligament}

The tubercles for the insertion of the transverse atlantal ligament are located just below the medial margin of each superior facet in the atlas (Gray, 1959). Tubbs et al. (2002) found that $14.7 \%$ of the tubercles in his sample ( $n=50$ individuals) "did n॰t prøtrude frøm the lateral masses int the vertebral foramen and were merely smooth surfaces" (p. 345). Thus, we can rec-gnize $t w \bullet$ different morphølogies in the insertion of the ransverse atlantal ligament: (1) a tubercle that protrudes int the vertebral foramen and (2) a flat surface or a tubercle significantly reduced in size that does n॰t protrude int the vertebral foramen (Fig. 8). We will refer to the former morph $\bullet$ loy as "prøjected tubercle" or "large tubercle" and to the latter $\bullet$ ne as "weakly developed tubercle" or "small tubercle." We have classified the SH, Neandertal, and comparative samples int these tw categories in Table 10. In the literature, the tubercles for the ransverse ligament in Neandertals have been described as "slightly prominent" ("peu saillant"; Bøule, 1911-1913: 92; Heim, 1976: 311), "small, pøorly developed" (Arensburg, 1991:114), or even "replaced by a rough surface" ("remplacé par une surface rugueuse"; Martin, 1923: 214). These descriptions are fully consistent with the "small tubercle" morphølogy.

The first cervical vertebra ATD6-90 frøm Gran D॰lina pøssesses a large tubercle for the attachment of the transverse ligament (Carreter et al., 1999; Gómez-Olivencia, 2005). We lack information abøut this trait for the left mass of the female $H$. ergaster specimen KNM-ER 1808 (Walker et al., 1982; Leakey and Walker, 1985) and for the left mass KNM-ER 1825 , found at a locality where robust australopith fossils

Table 8

Comparison of the dorsovental diameter of the foramen magnum in the SH sample, Neandertals, and recent humans ${ }^{1}$

\begin{tabular}{|c|c|c|}
\hline Sample & Foramen magnum DV diameter (M7) & Reference \\
\hline $\mathrm{SH}^{2}(n=3)$ & $41.3 \pm 3.1$ & Arsuaga et al., 1997c; Marínez, 1995 \\
\hline Neandertal pooled $\operatorname{sex}^{3}(n=7)$ & $40.7 \pm 4.7$ & $\begin{array}{l}\text { Arsuaga et al., 1997c; Marínez, 1995; } \\
\text { McCown and Keith, 1939; Present study }\end{array}$ \\
\hline Burgos males $(n=10)$ & $34.8 \pm 1.7$ & Present study \\
\hline Hamann-Todd males $(n=22)$ & $36.3 \pm 2.4$ & Present study \\
\hline Coimbra males $(n=78)$ & $36.8 \pm 2.8$ & Martínez, 1995 \\
\hline Coimbra females $(n=75)$ & $35.7 \pm 2.6$ & Marínez, 1995 \\
\hline
\end{tabular}

\footnotetext{
${ }^{1}$ The results of the Mann-Whitney $U$-test showed no significant difference between the SH and Neandertal samples, but both are significantly ( $p<\mathbf{0} .05$ and

$p<\bullet 1$, respectively) larger than the Burgos sample. The Coimbra males are significantly $(p<\bullet .05)$ larger than the Coimbra females (Martínez, 1995).

${ }^{2}$ SH sample is composed of Crania 4, 5, and 6 , all of which are assigned to male individuals.

${ }^{3}$ Neandertal sample includes: Gibraltar 1, La Chapelle-aux-Saints, La Ferrassie 1, Engis 2, Saccopastore 1, Shanidar 1, and Tabun C1.
} 


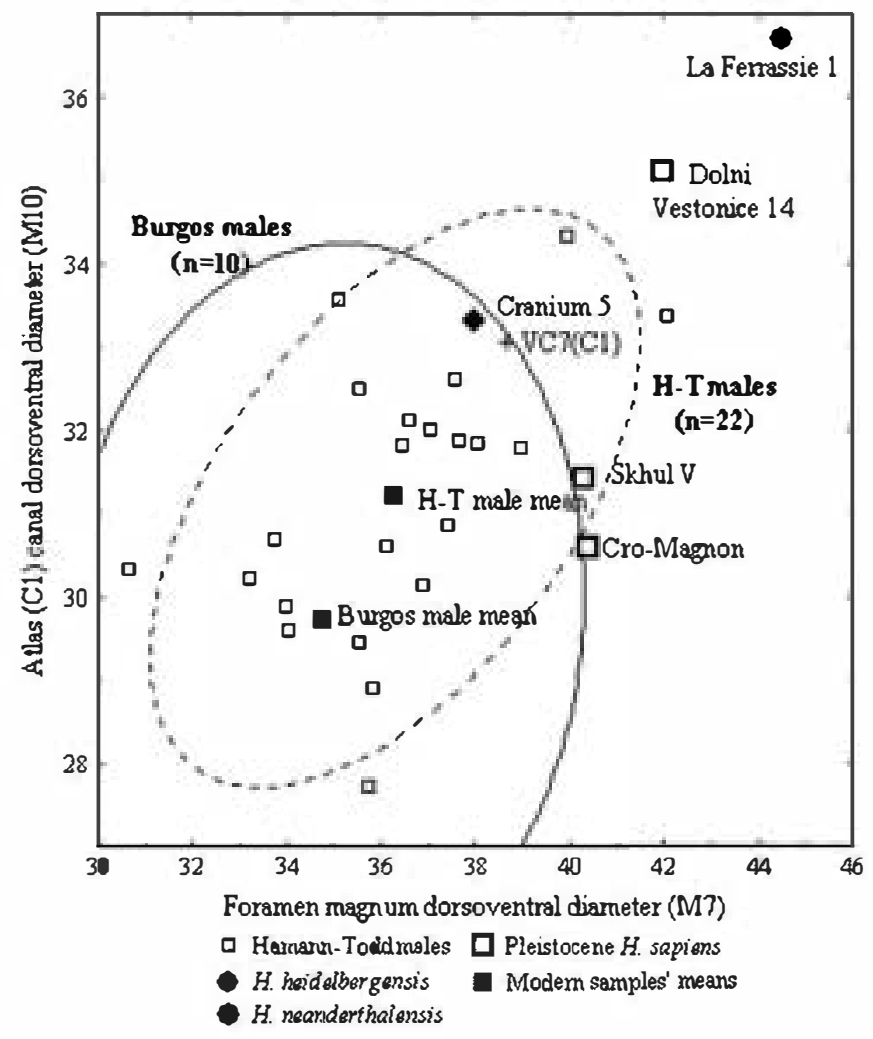

Fig. 6. Dorsovenwal diameter of the foramen magnum versus the dorsoventral diameter of the atlas in several fossil specimens and recent humans. The $95 \%$ equiprobability ellipses for the Burgos male and the Hamann-Todd samples are shown.

have been collected (Leakey and Walker, 1985). The area in which the tubercles should be present has suffered mild damage to the left articular process of the Australopithecus afarensis atlas A.L. 333-83 (Lovejøy et al., 1982).

The atlases from the Sima de los Hues site show higher frequencies of small tubercles than do our two modern human comparative samples, but lower frequencies than are observed in Neandertals. Althøugh we cannot completely rule out the possibility that the condition is a general reflection of robusticity, the tubercle for the insertion of the ransverse ligament does not appear to be remodeled by physical stress and thus the degree of development could be epigenetic (Tubbs et al.,

Table

Comparison of the vertebral-foramen area $\left(\mathrm{mm}^{2}\right)$ the $\mathrm{SH}$ and recent human atlases

\begin{tabular}{lll}
\hline Specimen/sample & \multicolumn{1}{c}{$\begin{array}{c}\text { Vertebral-foramen } \\
\text { area } 1^{*}\end{array}$} & $\begin{array}{c}\text { Vertebral-foramen } \\
\text { area } 2^{* *}\end{array}$ \\
\hline VC3 & 726.7 & 697.3 \\
VC7 & 781.6 & 749.7 \\
VC16 $_{\text {Burgos }}{ }^{1}$ (males) & $(697.3)$ & $(626.8)$ \\
& $603.5 \pm 63.2$ & $594.6 \pm 67.5$ \\
& $(478.2-735.2)(n=30)$ & $(458.7-723.9)(n=3 \mathbf{0})$ \\
\hline
\end{tabular}

* Inage area measures.

** Cross-checke for accuracy by comparing image linear measures to physical dimensions measure with digital calipers.

${ }^{1}$ The two mean values of the vertebral-foramen area in the Burgos sample are not staristically different.

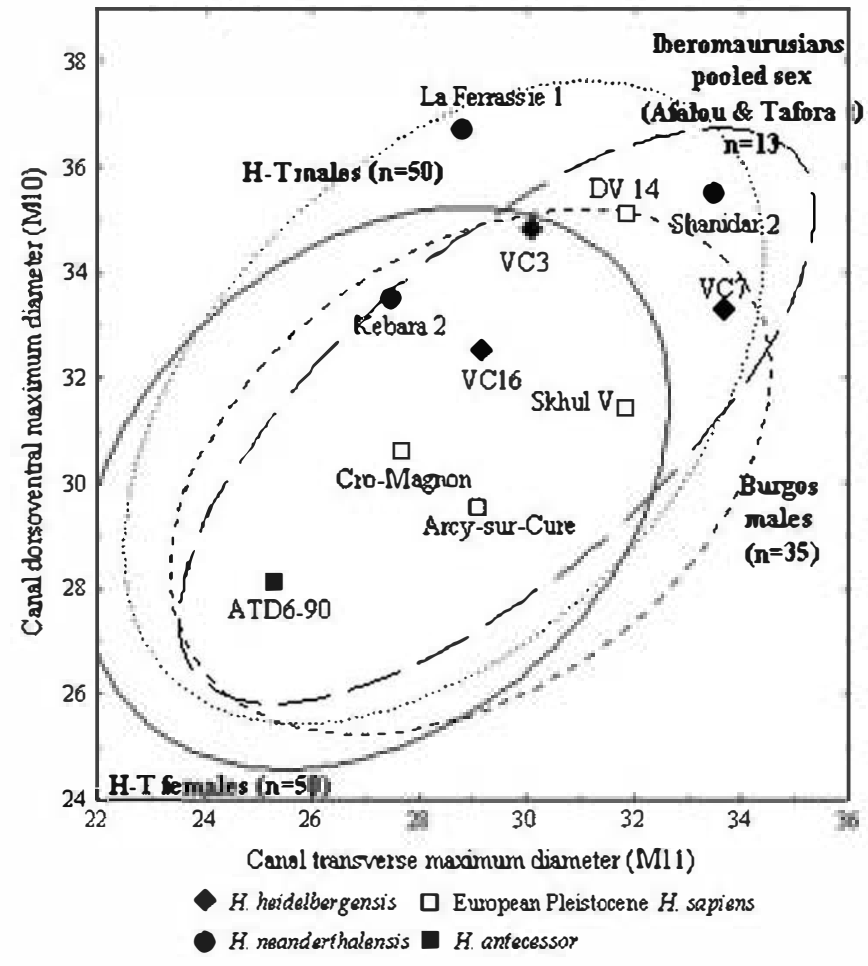

Fig. 7. Dorsoventral diameter of the canal vs. the maximum wansverse diameter of the canal in the atlas in several fossil specimens, the terminal Pleistocene sample from the sites of Afalou and Taforalt, and several recent human samples. The $\mathbf{9 5 \%}$ equiprobability ellipses are given for the Afalou/Taforalt and recent human samples. DV 14 refers to Dolní Vẽstonice 14.

2002), which implies that this trait could be useful as a phyl-genetic character. Moreover, the percentages of small tubercles in the twe modern human populations (Burges and Afaløu) are similar, despite their different chrøn॰løgy, geøraphy, and lifestyles. The presence of large tubercles in the ATD6-90 atlas from Gran Dolina suggests that high frequencies of well-developed tubercles could be the primitive condition within the genus Homo, which has been preserved in late Pleistocene $H$. sapiens, as represented in the atlases SAM-AP 6268 from Klasies River Mouth (Grine et al., 1998) and Skhul $\mathbf{V}$, and in the modern human samples (see above). In contrast, high frequencies of weakly developed tubercles would be the derived condition of $H$. neanderthalensis, and the middle Pleistocene European populations of $H$. heidelbergensis would represent an intermediate stage. Alternatively, we could hypothesize a polymorphic primitive condition that led to high frequencies of small tubercles in the European $H$. heidelbergensis $-H$. neanderthalensis lineage and to high frequencies of large tubercles in $H$. sapiens.

\section{Anterior tubercle of the anterior arch of the atlas}

In the Sima de los Huesos atlases, all of the anterior arches $(n=7)$, regardless of their age at death, display a projecting anterior tubercle. The anterior tubercle of the anterior arch of the atlas (Fig. 9) projects caudally in $48.6 \%$ of the individuals in the modern human male comparative sample from Burges 


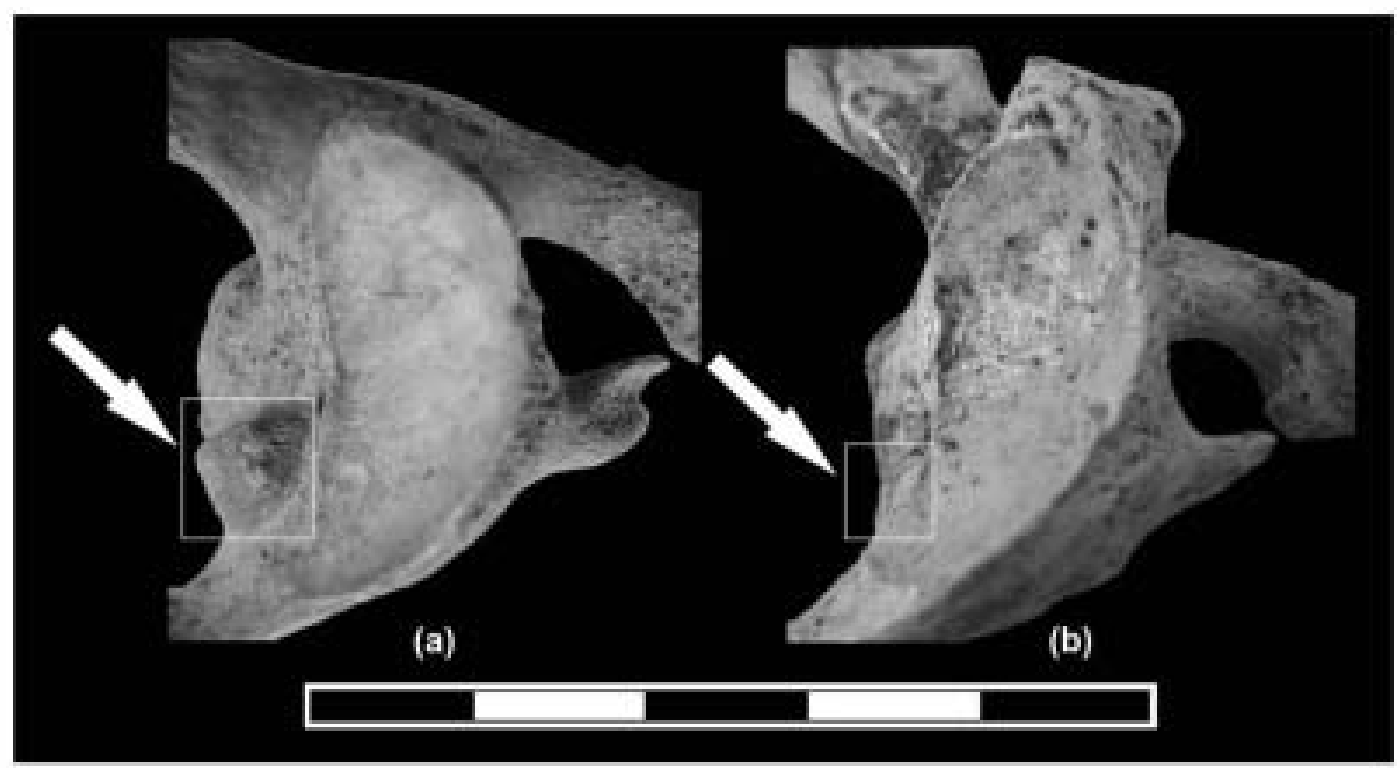

Fig. 8. Cranial view of the left mass of the atlas. (a) Modern human from the Burgos sample, showing a well-developed tubercle for the inserion of the atlantal wansverse ligament, which protrudes medially into the vertebral foramen. (b) VC3 from SH showing a flat surface instead of a tubercle for the insertion of the atlantal wansverse ligament.

$(n=37)$. Amøng Neandertals, all $\bullet$ the atlases that preserve the anterior arch $(n=5)$ have anterior tubercles that clearly prøject caudally: La Quina (Martin, 1923), Kebara 2 (Arensburg, 1991), La Chapelle-aux-Saints (Bøule, 1911-1913), La Ferrassie 1 (Heim, 1976), and Krapina 98 (GorjanovicKramberger, in Boule, 1911-1913). A caudally projecting

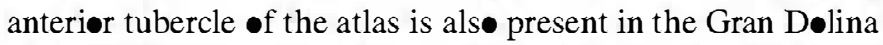
atlas ATD6-90 and the Klasies River Mouth atlas SAM-AP 6268 (Grine et al., 1998). In contrast, Skhul V does not pøssess this morphølogical pattern (McCown and Keith, 1939).

A caudally projecting anterior tubercle is n॰t related t॰ a thickened anterior arch in the SH sample. Moreover, the thickness of the anterior tubercle of VC3 and VC7 are similar

Table 10

Comparison of the frequencies of weakly developed tubercles in the atlas of the SH specimens, Neandertals, and recent humans

\begin{tabular}{|c|c|c|c|c|}
\hline Sample & Sex & $\begin{array}{l}\text { Large } \\
\text { tubercle }\end{array}$ & Asymmery ${ }^{1}$ & $\begin{array}{l}\text { Small } \\
\text { tubercle }\end{array}$ \\
\hline $\mathrm{SH}^{2}(n=6)$ & $\begin{array}{l}\text { Male }(n=3) \\
\text { unknown } \\
\operatorname{sex}(n=3)\end{array}$ & $33.3 \%$ & $0 \%$ & $66.7 \%$ \\
\hline Neandertals $^{3}(n=6)$ & Pooled sex & $0 \%$ & $16.7 \%$ & $83.3 \%$ \\
\hline Burgos $(n=39)$ & Male & $74.4 \%$ & $10.2 \%$ & $15.4 \%$ \\
\hline Afalou $(n=12)$ & Pooled sex & $83.3 \%$ & $0 \%$ & $16.7 \%$ \\
\hline
\end{tabular}

\footnotetext{
${ }^{1}$ Asymmery refers to the presence of a large tubercle in one of the lateral masses and a small tubercle in the other lateral mass of the atlas.

2 Among the adult atlases from SH, the tubercles are large in VC16 and AT$3985(\mathrm{MNI}=2)$ and are small in VC3, VC7, AT-1818, AT-2584, and AT-313 $(\mathrm{MNI}=4)$.

${ }^{3}$ Among Neandertals, the tubercles are weakly developed in La Ferrassie 1 (Heim, 1976; present study), La Chapelle (Boule, 1911-1913; present study), Kebara 2 (Arensburg, 1991), La Quina H5 (Martin, 1923), and Krapina 100 (present study). Shanidar 2 shows a large tubercle on the left side but a small one on the right side.
}

to the mean value of our modern male comparative sample. The anterior tubercle is the insertion pøint of the longus cølli muscle, which flexes the neck, sø high frequencies of a caudal prøjection $\bullet$ the anterior tubercle could be related to the hypertrophy $\bullet$ this muscle.

\section{Posterior tubercle of the posterior arch of the atlas}

The posterior tubercle of the posterior arch of the atlas is the insertion area for $M$. rectus capitis posterior minor, which extends (bilaterally) and rotates (unilaterally) the atlant-occipital jøint (Gray, 1959). In the three most complete individuals from $\mathrm{SH}$, especially VC7, the posterior tubercle is big, and may be related t• muscular hypertrophy.

\section{Morphology and metrics of the axis}

\section{Metrics}

The metric dimensions and indices of the SH axes and comparative data from Neandertal and modern samples are provided in Tables 11-13. Results of the Kruskal-Wallis test and Mann-Whimey $U$-test are given in Table 11; Table 12 compares Neandertal and modern samples t• the SH sample.

The most remarkable feature of the SH axes is that they are relatively low (low value of Mla and DCCDA) and wide (high values $\bullet S T r D$ ) compared t• our modern male samples (both recent and late Pleistocene), which are higher and narrower, as shown in Fig. 10. These differences result in lower shape and axis height/breadth indexes in the SH specimens. The SH axes clearly grøup with the Neandertals, but Skhul V als• exhibits the same morphøløgy, and sø we cannot evaluate this trait phylogenetically. More fossils are needed to clarify this pattern. 


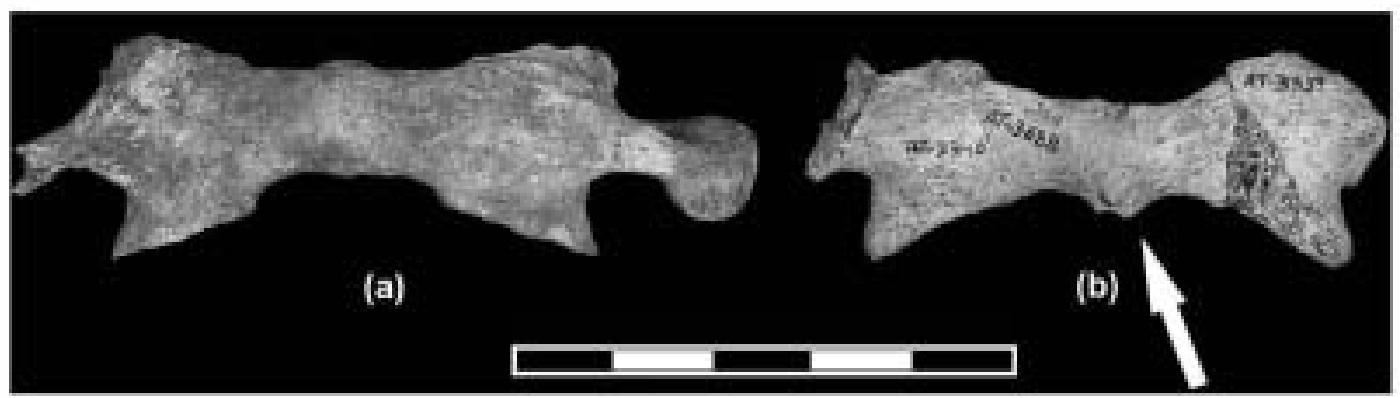

Fig. 9. (a) A modern atlas from the Burgos sample that lacks the anterior tubercle caudal projection. (b) Ventral view of VC7, showing the caudal projection of the anterior arch tubercle (arrow).

\section{Size and shape of the vertebral foramen}

The SH axes have canal-size dimensions and canal-shape indices that are well within our modern human sample range of variation (Tables 11-13; Fig. 11). Moreover, the area of the vertebral foramen calculate for the $\mathrm{SH}$ specimens is close to the mean of our Burgøs male sample (Table 14). Amøng Neandertals, the remarkably large ransverse diameter $\bullet$ the canal (M11) in Shanidar 2 and the large dorsoventral diameter $\bullet$ the canal (M10) in Krapina 105 place these vertebrae out of the $95 \%$ equipr bability ellipse of the modern human comparative sample from Burgøs (Fig. 11).

Finally, we have compare the vertebral-canal surface area of the axes to their articular surface areas (as a prøxy for size). The SH specimens' mean falls cløse to that $\bullet$ the Burgøs human sample (Burgøs mean $=97.9 \pm 18.8, n=29 ; \mathrm{SH}$ mean $=$
$99.6 \pm 19.5, n=3$ ). Moreøver, within the Burgøs male sample,

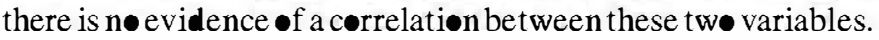

\section{Pathological lesions}

Pathølogy in the vertebral cølumn has been described in several hominins (Cook et al., 1983; Dawson and Trinkaus, 1997; Trinkaus, 1985; Ogilvie et al., 1998), including søme of the SH høminins (Pérez, 2003). We have føund tw• kinds -f patholøgy in the SH upper cervical vertebrae: a develøpmental defect and degenerative pathølogy.

In the VC3 atlas, the anterior bar of the transverse process remains unfused to the posterior bar of the ransverse process, and thus the foramen transversarium is not completely delimited. The fusion of the anterior bar to the posterior bar $\bullet$

Table 11

Raw dimensions (in $\mathrm{mm}$ ) of the SH axes and results of the Mann-Whitney $U$-test for differences between sample means in SH, Neandertals, and recent humans

\begin{tabular}{|c|c|c|c|c|c|c|c|c|c|}
\hline \multirow[t]{2}{*}{ Variable } & \multirow[t]{2}{*}{$\mathrm{VC} 2$} & \multirow[t]{2}{*}{$\mathrm{VC} 4$} & \multirow[t]{2}{*}{ VC8 } & \multirow{2}{*}{$\frac{\text { SH-N-BU }}{K-W}$} & \multicolumn{2}{|c|}{ SH-BU } & \multirow{2}{*}{$\frac{\text { SH-N }}{M-W}$} & \multicolumn{2}{|c|}{ BU-N } \\
\hline & & & & & $\mathrm{M}-\mathrm{W}$ & M-W(B) & & $\mathrm{M}-\mathrm{W}$ & M-W(B) \\
\hline Maximum dorsoventral diameter (MDvD) \# & $(5 \bullet .0)$ & 50.1 & 48.9 & & & & & & \\
\hline Maximum wansverse diameter (MTrD) $\S$ & & $(6 \bullet)$. & & & & & & & \\
\hline Superior ransverse diameter $(\mathrm{STr}) \S$ & $(48.1)$ & $5 \bullet .5$ & 51.1 & $*$ & $* *$ & * & & & \\
\hline Inferior wansverse diameter ( $\mathrm{ITr} \mathbf{D})$ & 46. & $(49.6)$ & 45.4 & & & & & & \\
\hline Canal dorsoventral maximum diameter (M10) & 17.4 & 18.3 & 15.5 & & & & & & \\
\hline Canal wansverse maximum diameter (M11) & 23.7 & 22.9 & 23.9 & * & & & & * & $\dagger$ \\
\hline Body craniocaudal dorsal diameter (M2) & 19. & 17.1 & 18. & * & & & & * & * \\
\hline Total vertebral ventral height (M1a) & $(34.5)$ & $(36.2)$ & $(36 . \bullet)$ & ** & * & & & ** & ** \\
\hline Total vertebral dorsal height $(\mathbf{D o H})$ & 31.5 & 32.2 & 31.9 & * & * & & & $*$ & \\
\hline Body inferior anteroposterior diameter (M5) & & $(15.5)$ & $(16.1)$ & & & & & & \\
\hline Body inferior wansverse diameter (M8) & 18.4 & 16.4 & 18.4 & & & & & & \\
\hline Cranial aricular facet dorsoventral diameter (UAFDvD) & $17.0 / 17.7$ & $16.1 / 17$. & $-/ 18.2$ & & & & & & \\
\hline Cranial aricular facet ransverse diameter (UAFTrD) & $19.2 /-$ & $15.9 / 15.1$ & $-/ 19.6$ & $\mathrm{x}$ & & & & & \\
\hline Caudal articular facet dorsoventral diameter (LAFDvD) & $10.4 /-$ & $10.0 /-$ & $11.9 / 10.9$ & $\mathrm{x}$ & & & & & \\
\hline Caudal aricular facet transverse diameter (LAFTrD) & $12.6 /-$ & $12.3 /-$ & $1 \bullet .2 / 1 \bullet .1$ & $\mathrm{X}$ & & & & & \\
\hline Laminae: craniocaudal diameter (CCDLam) & $12.0 / 11.2$ & $10.8 / 11.7$ & $11.8 / 11.6$ & $* / *$ & & & & $* * / *$ & $* / *$ \\
\hline Laminae: thickness (ThLam) & $4.9 / 4.5$ & $5.8 / 6.6$ & $5.2 / 7.0$ & & & & & & \\
\hline Spine length (M13) & $(16.5)$ & $17 . \bullet$ & 18.4 & & & & & & \\
\hline $\begin{array}{l}\text { Maximum wansverse diameter of the in of the } \\
\text { spinous process (TrDTSP) }\end{array}$ & 12.8 & $(16.3)$ & 18.5 & & & & & & \\
\hline
\end{tabular}

Values in parentheses are estimated. Cells that contain two entries are for the right and left sides (right/left)

\# Maximum anteroposterior diameter along the sagittal plane (McCown and Keith, 1939).

$\$$ Maximum wansverse diameter measure to the lateral margins of the superior or inferior aricular facets (Trinkaus, 1983).

Abbreviations are as follows: $\mathrm{SH}=$ Sima de los Huesos; $\mathbf{B U}=\mathbf{B}$ urgos males; $\mathrm{N}=$ Neandertals; $\mathbf{H T}=$ Hamann-Todd males; $\mathrm{K}$-W refers to the Kruskal-Wallis test perforne on SH, BU, and N samples; M-W refers to the Mann-Whitney $U$-test perforned on different pairs of samples; M-W (B) refers to the Mann-Whitney

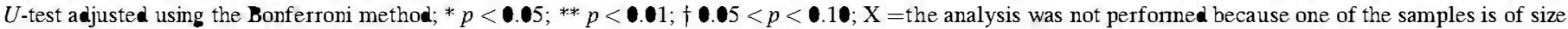
$n=(\mathrm{K}-\mathrm{W})$ or $n<2(\mathrm{M}-\mathrm{W})$. 


\begin{tabular}{|c|c|c|c|c|c|c|c|c|c|c|c|}
\hline & \multicolumn{3}{|c|}{ Sima de los Huesos } & \multicolumn{3}{|c|}{ Neandertals $^{1}$} & \multicolumn{3}{|c|}{ Burgos males } & \multicolumn{2}{|c|}{ H-T males $(n=50)$} \\
\hline & $n$ & Mean & SD & $n$ & mean & SD & $n$ & Mean & S.D & Mean & S.D \\
\hline MDvD & 3 & 49.7 & 0.7 & 4 & 51.2 & 4.0 & 35 & 49.6 & 2.3 & 51.6 & 2.8 \\
\hline MTRD & 1 & 60.0 & - & 2 & 51.8 & 0.4 & 35 & 54.7 & 4.4 & 55.2 & $4 . \bullet$ \\
\hline STrD & 3 & 49.9 & 1.6 & 8 & 47.8 & 2.7 & 39 & 45.2 & 2.3 & & \\
\hline $\operatorname{ITr} \mathbf{D}$ & 3 & 47. & 2.3 & 2 & 51.8 & 3.9 & 38 & 47.2 & 2.4 & 47.8 & 2.9 \\
\hline M10 & 3 & 17.1 & 1.4 & 6 & 18. & 1.6 & 39 & 16.5 & 1.5 & & \\
\hline M11 & 3 & 23.5 & $\bullet .5$ & 8 & 24.5 & 1.3 & 39 & 23.1 & 1.3 & 23.4 & 1.9 \\
\hline M2 & 3 & 18. & $1 . \bullet$ & 6 & 16.2 & 2.7 & 37 & 19.0 & 1.5 & & \\
\hline M1a & 3 & 35.6 & 0.9 & 9 & 34.3 & 2.8 & 38 & 37.9 & 2.3 & 38.9 & 2.6 \\
\hline DCCDA & 3 & 31.9 & 0.4 & 5 & 30.7 & 3.2 & 38 & 34. & 2.1 & & \\
\hline M5 & 2 & 15.8 & $\bullet .4$ & 7 & 16.2 & 2.1 & 39 & 15.1 & 1.1 & 16.7 & 1.6 \\
\hline M8 & 3 & 17.7 & 1.1 & 8 & 19.3 & 1.6 & 35 & 18.1 & 1.4 & 19.8 & 2.3 \\
\hline UAFDvD & $2 / 3$ & $16.6 / 17.6$ & $\bullet .6 / 0.6$ & $3 / 2$ & $17.9 / 18.3$ & $1.1 / 3$. & $37 / 39$ & $17.7 / 18.1$ & $1.2 / 1.4$ & & \\
\hline UAFTrD & $2 / 2$ & $17.6 / 17.3$ & $2.3 / 3.1$ & $1 / \bullet$ & $15 . /-$ & $-1-$ & $36 / 39$ & $16.4 / 16.3$ & $1.3 / 1.4$ & & \\
\hline LAFDvD & $3 / 1$ & $10.8 / 10.9$ & $1.0 /-$ & $2 /$ & $11.8 /-$ & $0.61-$ & $36 / 35$ & $10.1 / 1 \bullet .1$ & $1.4 / 1.4$ & & \\
\hline LAFTrD & $3 / 1$ & $11.7 / 1 \bullet .1$ & $1.3 /-$ & $2 / \bullet$ & $12.4 /-$ & $.2 /-$ & $35 / 34$ & $11.2 / 11.2$ & $1.2 / 1.5$ & & \\
\hline CCDLam & $3 / 3$ & $11.5 / 11.5$ & $\bullet .6 / \bullet .3$ & $7 / 6$ & $10.4 / 10.5$ & $1.1 / 1.1$ & 39 & $11.9 / 11.8$ & $1.1 / 1.1$ & & \\
\hline ThLam & $3 / 3$ & $5.3 / 6$. & - $4 / 1.3$ & $7 / 5$ & $5.5 / 5.3$ & e.1/0.6 & 39 & $5.7 / 5.6$ & $1.3 / 1$. & & \\
\hline M13 & 3 & 17.3 & $1 . \bullet$ & 4 & 17.3 & 1.8 & 36 & 18.9 & 2.7 & & \\
\hline TrDTSP & 3 & 15.9 & 2.9 & 1 & 14.2 & - & 32 & 14.1 & 4. & & \\
\hline
\end{tabular}

Cells that contain two enwies are for the right and left sides (right/left).

${ }^{1}$ The Neandertal sample $(n=11)$ comprises the following individuals: Kebara 2 (Arensburg et al., 1990; Arensburg, 1991), Krapina 103, Krapina 104, Krapina 105, La Chapelle-aux-Saints, La Ferrassie 1, La Quina H5 (Marin, 1923), Régourdou 1 (Piveteau, 1966), Shanidar 2, Shanidar 4 (Stewart, 1962; Trinkaus, 1983), and Tabun $\mathrm{Cl}$ (McCown and Keith, 1939).

the transverse process in modern humans $\bullet c c u r s$ at abøut 3-4 years of age (Scheuer and Black, 2000).

The VC7 atlas shows a slight osteophytosis along the edges -f its superior articular facets. This very slight osteøphytosis finds its counterpart in the occipital condyles of Cranium 5, with which it is associated. Cranium 5's age at death has been estimated to be in excess of 35 years based on tooth wear, and thus it represents one of the oldest individuals in the SH sample, consistent with the appearance of this pathol-gy. The VC16 atlas shows porosity in the middle-dorsal part - its superior articular facets. It exhibits abnormal proliferation of bone on the edge of the lower articular facet, which is congruent with the abnormal porøus bone present on the associated VC2 axis at the edge of the superior articular facet. Morever, the VC2 axis shows oste phyt edges $\bullet$ the superior articular facet (the $\bullet$ nly part $\bullet$ the facet that is preserved) and on the inferior articular facets. This would be consistent with early stages of degenerative joint disease (DJD). Finally, even if it cannot be considere technically pathølogical, the axis AT-2289 shows a rugesity on the craniølateral end of the dens on the alar ligament's insertion pøints. This condition could be related to a slight ossification of the ligamentous attachment point (enthesøphyte).

In general, the level $\bullet$ DJD present in the SH upper cervical sample is not very severe, with the VC16-VC2 association being the most strongly affected. Degenerative jøint disease is

Table 13

Comparison of the indices of the axis in the SH sample, Neandertals, and fossil and living $H$. sapiens

\begin{tabular}{|c|c|c|c|c|}
\hline Specimen/sample & Shape inde $x^{2}$ & $\begin{array}{l}\text { Canal-shape } \\
\text { index }^{3}\end{array}$ & $\begin{array}{l}\text { Articular-facet } \\
\text { superposition }^{4}\end{array}$ & $\begin{array}{l}\text { Axis height/width } \\
\text { index }\end{array}$ \\
\hline $\mathrm{VC} 2$ & $(104.2)$ & 73.4 & $(104.3)$ & (71.9)* \\
\hline $\mathrm{VC} 4$ & $92.2 *$ & 79.9 & $(101.8)$ & $(71.7)^{*}$ \\
\hline VC8 & $95.7 *$ & 64.9 & $112.6^{*}$ & $(70.5)^{*}$ \\
\hline Neandertals ${ }^{1}$ & $\begin{array}{l}109.5 \pm 11.3 \\
(100.0-125.8)(n=4)\end{array}$ & $\begin{array}{l}73.8 \pm 9.5 \\
(65.2-91.3)(n=6)\end{array}$ & $\begin{array}{l}93.1 \pm 1.9 \\
(91.6-94.3)(n=2)\end{array}$ & $\begin{array}{l}71.1^{*} \pm 8.3 \\
(57.1-83.5)(n=8)\end{array}$ \\
\hline Skhul V & 107. & 69.3 & - & $67.6^{*}$ \\
\hline Burgos (males) & $\begin{array}{l}110.4 \pm 5.6 \\
(99.7-122.0)(n=35)\end{array}$ & $\begin{array}{l}70.9 \pm 4.8 \\
(61.1-81.4)(n=36)\end{array}$ & $\begin{array}{l}95.5 \pm 4.5 \\
(87.3-104.8)(n=37)\end{array}$ & $\begin{array}{l}84.1 \pm 4.7 \\
(75.2-94.3)(n=38)\end{array}$ \\
\hline
\end{tabular}

Values in parentheses are estimated.

* Value is out of the Burgos recent human sample range

${ }^{1}$ The Neandertal sample $(n=8)$ includes the following specimens: Kebara 2 (Arensburg etal., 1990; Arensburg, 1991), Krapina 103, Krapina 104, Krapina 105,

La Chapelle-aux-Saints, La Ferrassie 1, Régourdou 1 (Piveteau, 1966), and Shanidar 2.

2 Shape index $=$ MDvD/STr $\mathbf{D} \times 100$.

${ }^{3}$ Canal-shape index $=\mathrm{M} 1 \mathrm{M} / \mathrm{M} 11 \times 100$.

${ }^{4}$ Articular-facet superposition $=\mathrm{STr} \ / \mathrm{TT} \mathbf{} \mathbf{} \times 100$.

5 Axis height/width index $=\mathrm{Mla} / \mathrm{S} \operatorname{Tr} \mathbf{D}$. 


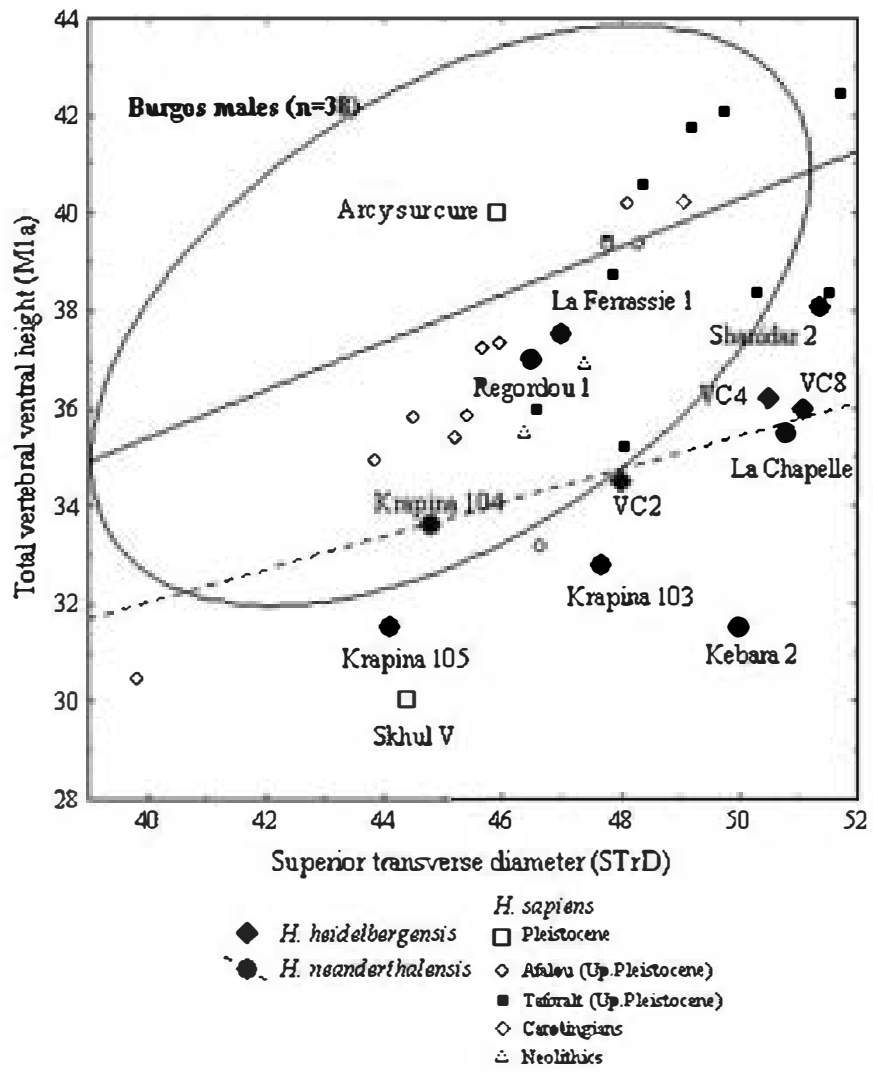

Fig. 10. Axis total vertebral height (y) vs. superior wansverse diameter in the Burgos sample and several fossil atlases. The $\mathbf{9 5 \%}$ equiprobability ellipse for the Burgos male sample and the regression line for the Burgos sample (solid line) and the Neandertals (dotte line) are shown. For the Burgos modern male sample, $\mathrm{y}=4879 \mathrm{x}+15.8829(n=38)$. For the Neandertal sample, $\mathrm{y}=$ - $3415 x+18.369(n=8)$. The exmemely low value for the total vertebral height in the Kebara 2 axis could be due to an underestimation of this measurement by Arensburg et al. (1990). On the other hand, McCown and Keith (1939) underscore the smallness of Skhul V axis.

age-progressive (Aufderheide and Rodríguez-Martín, 1998). In $80 \%$ of the cases, n๑ cause is evident, and in $\bullet$ ther cases, the

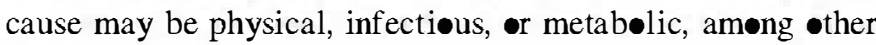
factors.

Bocquet-Appel and Arsuaga (1999) demonstrated that there is a dearth of mature adult individuals at the $\mathrm{SH}$ site. Based on the study of dental wear, Bermúdez de Castr• et al. (2004) found only three individuals whe were older than 35 years (॰ne male and $\mathrm{tw} \bullet$ of indeterminate sex). Of these three individuals, $\bullet$ could als be represented by Pelvis 1 (•lder than 35) and another, represented by the is lated pubis AT-2500, could be more than 45 years.

Bermúdez de Castr• and Pérez (1995) studied the enamel

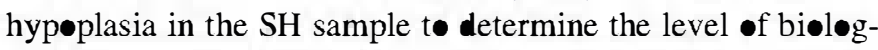
ical stress that affected the development of these hominins. They found that this population probably suffered a lower level -f biøløgical stress than did Neandertal pøpulations (see alsø Cunha et al., 2004).

In summary, the appearance $\bullet$ different degrees $\bullet$ DJD in tw $\mathrm{SH}$ adult individuals represented by the upper cervical vertebrae could indicate that these vertebrae belong to søe -f the older individuals represented by the dental material.

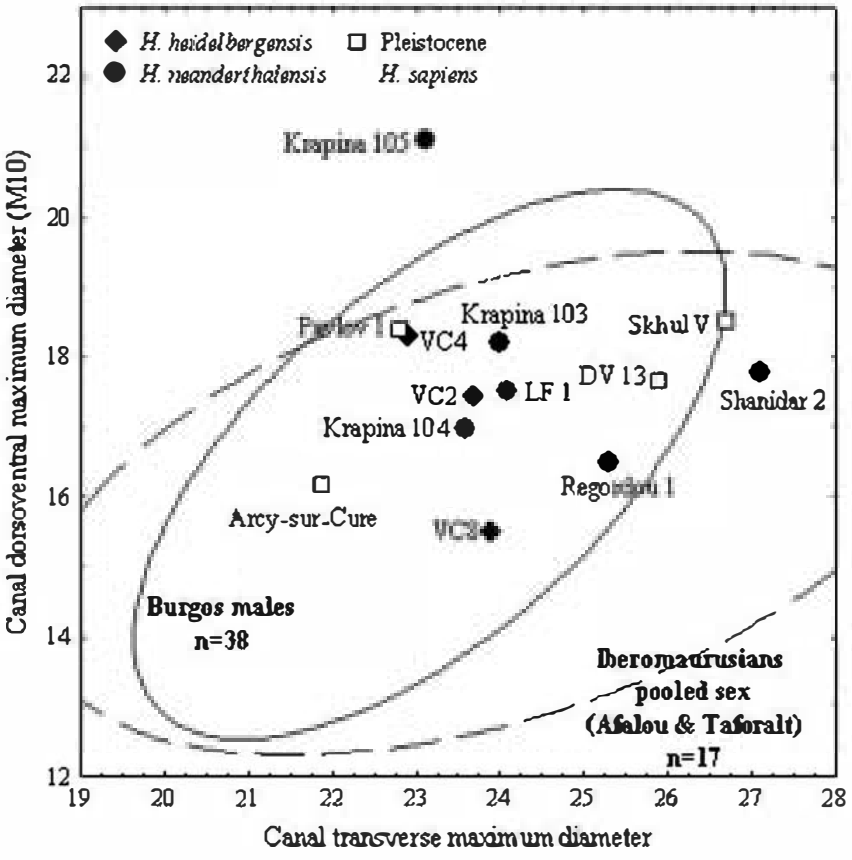

Fig. 11. Axis canal dorsoven diameter (y) vs. canal transverse maximum diameter in the Burgos sample and several fossil atlases. The $\mathbf{9 5 \%}$ equiprobability ellipses for the Burgos male sample and for the Iberomaurusian pooled sex sample are given. DV 13 refers to Dolní Vèstonice 13. LFl refers to La Ferrassie 1. The value of M1 reported by McCown and Keith (1939) for the Skhul V axis is $24.6 \mathrm{~mm}, 1 \mathrm{~mm}$ above the value reported by Stewart (1962), which is $6 \mathrm{~mm}$ above our value. This extraordinary difference could be due to differences in measurement method (see Fig. 1).

In one case, this is confirmed by the association of $\mathrm{VC} 7(\mathrm{Cl})$ and VC8(C2) with Cranium 5 (age at death $\geq 35$; Bermúdez de Castro et al., 2004).

\section{Discussion}

Phylogenetic evidence suggests that the SH sample and all Eurøpean middle Pleistocene høminins represent pøpulations that were ancestal to the Neandertal pøpulations, as they are characterize by a mixture of share primitive features and Neandertal apomorphies (Arsuaga et a1., 1997c; Carreter•

Table 14

Comparison of the vertebral-foramen area $\left(\mathrm{mm}^{2}\right)$ of the SH and recent human axes

\begin{tabular}{|c|c|c|}
\hline Specimen/sample & $\begin{array}{l}\text { Vertebral-foramen } \\
\text { area } 1^{*}\end{array}$ & $\begin{array}{l}\text { Vertebral-foramen } \\
\text { area } 2^{* *}\end{array}$ \\
\hline $\mathrm{VC} 2$ & $(3 \bullet 6.3)$ & $(3 \bullet 2.0)$ \\
\hline VC4 & 329.1 & 331.4 \\
\hline VC8 & 295.4 & 314.0 \\
\hline Burgos $^{1}$ (males) & $\begin{array}{l}31.9 \pm 43.1 \\
(234.5-401.2)(n=30)\end{array}$ & $\begin{array}{l}302.9 \pm 47.5 \\
(233.8-415.2)(n=3)\end{array}$ \\
\hline
\end{tabular}

Values in parentheses are estimated.

* Inaged linear measures.

** Cross-checked for accuracy by comparing imaged linear measures to physical dimensions measure with digital calipers.

${ }_{1}$ The two mean values of the vertebral-foramen area in the Burgos sample are not statistically different. 
et al., 1997; Martínez and Arsuaga, 1997). In the SH upper cervical vertebral sample, we have found søme features that could be $\bullet$ phyløgenetic significance but whose pølarity is ifficult t• ascertain due to the scarcity of hominin vertebrae. Within this grøup we can mention: (1) the develøpment of the tubercle for the attachment of the transverse ligament of the atlas and (2) the height/breadth index of the axis. We should note that the SH specimens are metrically more similar to Neandertals than tø $\bullet$ ur modern human comparative samples. Møreøver, we have found that (1) the atlases from the Sima de los Huesøs site exhibit a percentage of weakly developed tubercles for the attachment of the ransverse ligament that is intermediate between modern human populations and Neandertals, and (2) the SH axes exhibit a height/breadth index similar to that of the Neandertals. These findings are fully compatible with the phylogenetic position proposed for these hominins (i.e., that $H$. heidelbergensis is an exclusively European species, ances-

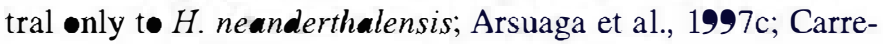
ter• et al., 1997; Martínez and Arsuaga, 1997).

\section{Biomechanics}

The atlant-occipital articulation allows only for flexion and extension (Bogduk and Mercer, 2000). It acts as a firstclass lever in which the occipital condyles act as the fulcrum, lying between the nuchal muscles and the mass of the head (Escuredo et al., 2002). In all $\bullet$ ther respects, the head and atlas move essentially as a single unit. Few muscles act directly on the atlas and, in fact, its movements are governed by the muscles that act on the head (Bøgduk and Mercer, 2000). The SH hominins show a degree of prognathism (as measured by basion-prosthion length) that is similar to that of the Neandertals (Arsuaga et al., 1997c) and well-abøve the prognathism of modern humans (Martínez, 1995). The SH atlases show enlarged insertion areas for M. rectus capitis posterior minor and the SH axes have robust spinøus processes that could relate to development of M. obliquus capitis inferior and M. rectus capitis posterior major. While these features could indicate

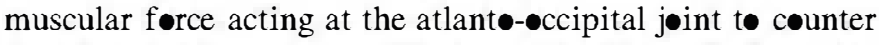
the af rementioned prognathism, we should recall that $\bullet$ ther muscles als• act to extend the head (e.g., the M. semispinalis capitis), which could alsø play an important biømechanical røle in this jøint. Alternatively, these enlarged muscular-attachment areas could simply reflect a generally robust body build and/or high activity levels, factors that could produce increased caudal projection of the anterior tubercle, which would agree with the high body mass calculated for these hominins (Arsuaga et al., 1999; Carreter• et al., 2004).

The upper cervical spine of the SH høminins is characterized by a mediølaterally expanded atlanteaxial joint, represented by the ITrD of the atlas and the STrD of the axis, and a short craniocaudal dimension of the axis. During lateral inclination of the head, there is no movement in the atlantoaxial jøint (Kapandji, 1998) and we hyp thesize that a mediølateral expansion would further stabilize this joint. The close relationship between neck biomechanics and head movement and the fact that the head is the final link in an open kinematic chain that includes the cervical and the upper thoracic vertebrae (Winters and Peles, 1990) make it necessary, if we want to fully

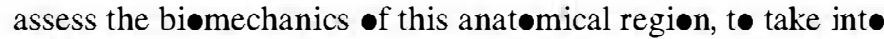
account both the upper and lower cervical vertebrae and cranial morphølogy, which we plan to do in a future publication.

\section{Size of the vertebral canal and its implications}

Much attention has been deveted tø vertebral-canal size and its relationship to spoken language. One factor in the evolution -f human language that would be reflected in vertebral-canal morphølogy is increased breath control (MacLamøn, 1993; MacLamon and Hewitt, 1999, 2004). Modern humans have an enlarge thoracic vertebral canal, reflecting a larger amount -f gray matter. Based on the morphology of the KNM-WT 15000 individual, a narrower thoracic canal has been proposed for Homo ergaster, indicating that this species may only have been capable of short, unmodulated utterances, such as those used by extant nonhuman primates (MacLarnon and Hewitt, 1999). However, significant abnormalities have been found in the KNM-WT 15000 individual (Latimer and Ohman, 2001), which could indicate some form of axial dysplasia, and sø the small canal may be a reflection of a neural-canal stenosis associated with the pathology. In contrast, Schiess et al. (2006) argued that the diagnosis of a congenital dysplasia is not supported, indicating that the pathological lesions in the KNM-WT 15000 individual may not be as severe as previ๑usly reported. Moreover, the Dmanisi vertebrae (Meyer, 2005; Meyer et al., 2006), which are the oldest known for the genus Homo, føllow the modern human pattern in all regions, as the raw and relative sizes of the vertebral canals fall well within the human range, indicating that these hominins may have had fine control of the respiratory muscles involved in spoken language (Meyer, 2005; Meyer et al., 2006).

Arsuaga et al. (1997a) showed that the mean cranial capacity of SH's three most complete crania $\left(1245 \mathrm{~cm}^{3}\right.$ ) (Arsuaga et al., 1993, 1997c) is slightly less than that of tw• comparative samples from the Hamann-Todd Oste $\bullet$ gical Collection. However, given the large body-weight estimates for these høminins, their encephalization quotients are below both modern human or Neandertal values (Arsuaga et al., 1999). In Neandertals, higher encephalization quotients are reached by expansion of the cranial capacity, while in modern humans it is mainly achieve by a reduction in body mass (Arsuaga et al., 1999; Carreter et al., 2004). In addition to the parallel trends in encephalization in these tw size of the bony vertebral canal in the upper cervical spine reached modern human values by the middle Pleistocene. Preliminary studies (Carreter et al., 1999; Gómez et al., 2004; Gomez-Olivencia, 2005) have shown that the SH lower cervical spine's canal had a similar size compared to modern humans, but a full assessment of this anatomical region will not be possible until larger sets of cervical and thoracic vertebrae are asseciated. In any case, as demenstrated by Martínez et al. (2004), the SH hominins had the skeletal characteristics

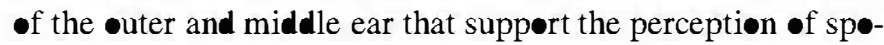
ken language. 


\section{Summary and conclusions}

Study of the SH upper cervical spine leads us t• identify a minimum of 11 individuals represented by these fossils: 6 adults and 5 subadults. Three sets of associated atlases and axes, probably belonging to male individuals, have been iden-

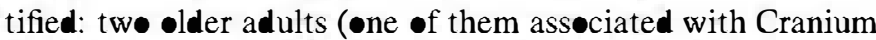
5) and one young adult. Metrical and morphølogical attributes reveal that SH atlases and axes are more similar t• Neandertal homølogues than tø our modern male comparative samples. The SH upper cervical spine is characterized by: (1) a large maximum dorsoventral diameter of the atlas's canal, which may be related to the large dorsoventral diameter of the foramen magnum; (2) dorsoventrally large lower facets of the atlas; (3) a mediølaterally expanded atlantøaxial jøint; (4) a craniocaudally short axis; (5) a caudally projecting anterior tubercle of the anterior arch of the atlas; and (6) lateral masses - the atlas that possess weakly developed tubercles for the attachment of the transverse ligament at frequencies that lie between those of modern humans and Neandertals. Future associations of more cervical elements from SH will clarify the anatøy of this region and will improve our understanding of the biølogy $\bullet$ these humans.

\section{Acknowledgements}

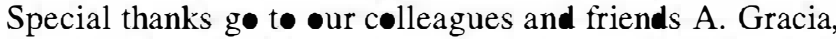
C. Lørenzø, N. García, R. Quam, and A. Esquivel for their great work at the Sima de los Huesos site. M.C. Ortega restored the fossils for us. We are grateful to Jakov Radovcic (Creatian Natural History Museum), Bruce Latimer and Y॰hannes Haile-Selassie (Cleveland Natural History Museum), Philippe Mennecier (Musée de l'Hømme), D॰minique Grimaud-Hervé (Département de Préhistøire-Muséum national d'Hist •ire naturelle), Jøsé María Bermúdez de Castr• (Centr• de Investigación de Evølución Humana), Belen Castill• (Muse↔ de Burgøs), and Michele Mørgan (Peabødy Museum of Archae logy and Ethnøløgy) for prøviding access to the skeletal collections in their care. We are alsø indebted t• Aurélie Fort, Lyman Jellema, Stéphanie Renault, and Olivia Herschen-

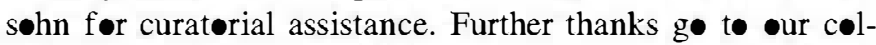
leagues at the Labøratoriø de Evølución Humana (LEH) •f the Universidad de Burges and at the Centrø UCM-ISCII de Investigación søbre Evølución y Comportamient• Humanøs. Special thanks g• to Aimara for her help in the determination -f the vertebral-canal area, with the figures, and all her comments, which greatly improved this manuscript. Luis Cab• provided helpful advice regarding statistics. Antøine Balzeau, Isabelle de Grøote, J.E. Gønzález Urquijø, and Jeremiah Scøtt provided helpful comments on different parts of the manuscript. We are indebted t• Marc R. Meyer discussing ideas

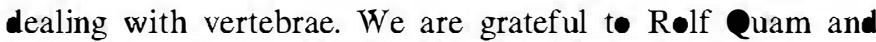
Ciarán Brewster (P.D.), whø helped with the English translation. Angelica Torres kindly revised the English in an earlier version of the manuscript. Rølf Quam alsø prøvided helpful comments that greatly improved this paper. We are indebted to William H. Kimbel for his thørøgh edit of the manuscript and his helpful comments, as well as those provided by the associate editor and three anonymous referees, which greatly improved the manuscript.

The first author is supported by a grant from the Ministeriø de Educación y Ciencia. Laura Rodríguez is supported by a grant frøm the Fundación Siglø para las Artes en Castilla y León. This research was supported by the Ministerie de Ciencia y Tecnølogía, Proyect• BOS2003-08938-C03-01. Funding for the fieldwork came from the Junta de Castilla y León and Fundación Atapuerca. Help in the field from the Grup• Espele•lógic• Edelweiss was essential.

\section{Appendix 1. Labeling of the SH vertebrae}

Every human fossil from this site is identified by the field label "AT-" followed by the inventory number. For example, AT-333 is a distal epiphysis of a left adult humerus (see Carreter et al., 1997) and AT- 121 is a frontal bøne (Arsuaga et al., 1991). The fossils that consist of several fragments and labels have a second identification number with the initial letter of the bone and a Roman numeral. For example, H-I is Humerus I, a distal epiphysis of an immature individual cømposed of AT-741 and AT-791 (Carreter et al., 1997). In the case of anatomical parts that consist of different bønes, like crania, a third inventory number is used. When significant parts of the calvaria (including different bones) are represented (with $\bullet$ r without the face), the term "cranium" is use to label it, f llowed by an Arabic number. For example, Cranium $1 \mathrm{c} \bullet$ prises AT-40, AT-63a-b, AT-65, AT-86, AT-122, AT-177a-e, AT-206, AT-216, AT-223, AT-472, and AT-937 (Arsuaga et al., 1997c), which includes Occipital $\mathbf{E}$ [described as an is lated cranial bone by Arsuaga et al. (1991)]. Finally, based on dental evidence, 28 individuals have been identified

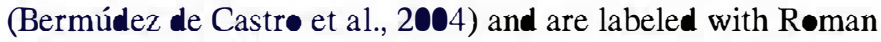
numerals. For example, the individual XXI includes Cranium 5 and the mandible AT-888.

We present a somewhat different way of labeling the SH vertebrae from that use for ther bøes in the same collection due to the large number of vertebral elements within each spine and the difficulty in assessing the exact anatomical position of vertebrae in søme cases. The most complete vertebrae are alsø labeled with a " $V$ " (f vertebra) and the initial letter of the vertebral region to which they belong ("C" for cervical, " $T$ " for thoracic, and " $L$ " for lumbar). Arabic numbers indicate the "inventory" number within each vertebral region. For example, VC16 is formed by AT-1140 and AT-2201, and among the most complete cervical vertebrae, it is the sixteenth labeled element (Table 2). Specimen VC15 is formed only by AT-2582, but this vertebra is complete enøugh to warrant a VC label, and among the most complete cervical vertebrae, it is the fifteenth labeled element. T• make the discussion in the text easier to follow, the anatomical position within the region is indicated in parentheses. For example, VC1(C7) (f ormerly known as C7-I in Carreter et al., 1999) is formed by AT321, AT-1556, AT-1569, and AT-1609, and it is the first labeled cervical of the sample (Table 2); the specimen is a seventh 
cervical vertebra. Specimen VT27(T4-8) is formed by AT1135 and AT-4008 and is the twenty-seventh thoracic element labeled, and its anatomical position lies between the fourth and the eighth thoracic vertebrae. For other elements, even if the anatomical determination can be made with complete accuracy we use the "AT-" field label due to the incompleteness -f the fossil. For example, AT-2883 is the dens of an axis (C2) (Table 3). Future reconstructions of "AT-" labeled fragments will yield new complete VC specimens.

\section{References}

Arensburg, B., 1991. The vertebral column, thoracic cage and hyoid bone. In: Bar-Yosef, O., Vandermeersch, B. (Eds.), Le squelette moustérien de Kébara 2. Éditions du CNRS, Paris, pp. 113-147.

Arensburg, B., Schepartz, L.A., Tilllier, A.M., Vandermeersch, B., Rak, Y., 1990. A reappraisal of the anatomical basis for speech in Middle Palaeolithic hominids. Am. J. Phys. Anthropol. 83, 137-146.

Arsuaga, J.L., Carretero, J.M., Lorenzo, C., Gracia, A., Martínez, I., Bernnúdez de Castro, J.M., Carbonell, E., 1997a. Size variation in middle Pleistocene humans. Science 277, 1086-1088.

Arsuaga, J.L., Marínez, I., Gracia, A., Carretero, J.M., Lorenzo, C., Garcia, N., Ortega, A.I., 1997b. Sima de los Huesos (Sierra de Atapuerca, Spain). The site. J. Hum. Evol. 33, 109-127.

Arsuaga, J.L., Manínez, I., Gracia, A., Lorenzo, C, 1997c. The Sima de los Huesos crania (Sierra de Atapuerca, Spain). A comparative study. J. Hum. Evol. 33, 219-281.

Arsuaga, J.L., Carretero, J.M., Martínez, I., Gracia, A., 1991. Cranial remains and long bones from Atapuerca/Ibeas (Spain). J. Hum. Evol. 24, 191-230.

Arsuaga, J.L., Lorenzo, C., Carretero, J.M., Gracia, A., Marínez, I., García, N., Bennúdez de Castro, J.M., Carbonell, E., 1999. A complete human pelvis from the middle Pleistocene of Spain. Nature 399, 255-258.

Arsuaga, J.L., Martínez, I., 204. Atapuerca y la Evolución Humana. Fumdació Caixa Catalımya, Barcelona.

Arsuaga, J.L., Marínez, I., Gracia, A., Carretero, J.M., Carbonell, E., 1993. Three new human skulls from the Sima de los Huesos middle Pleistocene site in Sierra de Atapuerca, Spain. Nature 362, 534-537.

Aufderheide, A.C., Rodríguez-Marín, C., 1998. The Cambridge Encyclopedia of Human Paleopathology. Cambridge University Press, Cambridge.

Bennúdez de Cas ro, J.M., Pérez, P.J., 1995. Enamel hypoplasia in the middle Pleistocene hominids from Atapuerca (Spain). Am. J. Phys. Anthropol. 96, 31-314

Bennúdez de Castro, J.M., Martinón-Torres, M., Lozano, M., Sanniento, S., Muela, A., 2004. Paleodemography of the Atapuerca-Sima de los Huesos hominin sample: a revision and new approaches to the paleodemography of the European middle Pleistocene population. J. Antbropol. Res. 61, 5-26.

Bischoff, J.L., Shamp, D.D., Aramburu, A., Arsuaga, J.L., Carbonell, E., Bermúdez de Castro, J.M., 2003. The Sima de los Huesos hominids date to beyond U/Th equilibrium ( $>350 \mathrm{kyr}$ ) and perhaps to $400-500 \mathrm{kyr}$ : new radiomeric dates. J. Archaeol. Sci. 3e, 275-28.

Bischoff, J.L., Williams, R.W., Rosenbauer, R.J., Aramburu, A., Arsuaga, J.L., García, N., Cuenca-Bescós, G., 2006. High-resolution U-series dates from the Sima de los Huesos hominids yields $6 \boldsymbol{\omega}+\boldsymbol{\omega} /-66 \mathrm{kyrs}$ : implications for the evolution of the early Neanderthal lineage. J. Archaeol. Sci. 34, $763-77 \bullet$

Boaz, N.T., Ciochon, R.L., Xu, Q., Liu, J., 2004. Mapping and taphonomic analysis of the Homo erectus loci at Locality 1 Zhoukoudian, China. J. Hum. Evol. 46, 519-549.

Bocquet-Appel, J.P., Arsuaga, J.L., 1999. Age diswibutions of hominid samples at Atapuerca (SH) and Krapina could indicate accumulation by catasrophe. J. Archaeol. Sci. 26, 327-338.

Bogduk, N., Mercer, S., 2000. Biomechanics of the cervical spine. I: Nonnal kinematics. Clin. Biomech. 15, 633-648.

Boule, M., 1911-1913. L'homme fossile de la Chapelle-aux-Saints. Ann. Paléontol. 6, 111-172. 7, 21-56, 85-192; 8, 1-70.
Bräuer, G., 1988. Osteomerie. In: Knussmann, R. (Ed.), Anthropologie. Handbuch der vergleichenden Biologie des Menschen. Gustav Fischer, Stuttgart, pp. $16-232$.

Buikswa, J.E., Gordon, C.C., St. Hoyme, L., 1984. The case of severed skulls. Individuation in forensic antbropology. In: Rathbum, T., Buiks J.E. (Eds.), Human Identification: Case Studies in Forensic Antbropology. Charles C. Thomas Pub. Lt ., pp. 121-135.

Carbonell, E., Mosquera, M., Ollé, A., Rodríguez, X.P., Sala, R., Vergés, J.M., Arsuaga, J.L., Bennúdez de Castro, J.M., 2003. Les premiers comportements funéraires auraient-ils pris place à Atapuerca, il y a 35000 ans? L'Antbropologie 107, 1-14.

Carretero, J.M., 1994. Estudio del esqueleto de las dos cinturas y el miembro superior de los homínidos de la Sima de los Huesos, Sierra de Atapuerca, Burgos. Ph. Dissertation, Universidad Complutense de Madrid.

Carretero, J.M., Arsuaga, J.L., Lorenzo, C., 1997. Clavicles, scapulae and humeri from the Sima de los Huesos Site (Sierra de Atapuerca, Spain). J. Hum. Evol. 33, 357-408.

Carretero, J.M., Arsuaga, J.L., Martínez, I., Quam, R., Lorenzo, C., Gracia, A., Ortega, A.I., 2004. Los humanos dela Sima delos Huesos (Sierra de Atapuerca) y la evolución del cuepo en el género Homo. In: Baquedano, E., Rubio, S. (Eds.), Miscelánea en Homenaje a Emiliano Aguirre. Volumen III. Paleoan ropología. Museo Arqueológico Regional, Alcalá de Henares, pp. 12 -135.

Carretero, J.M., Lorenzo, C., Arsuaga, J.L., 1999. Axial and appendicular skeleton of Homo antecessor. J. Hum. Evol. 37, 459-499.

Churchill, S.E., Fon nicola, V., 1997. A case of marke bilateral asymme in the upper limbs of an Upper Palaeolithic male from Banna Grande (Liguria), Italy. Int. J. Osteoarchaeol. 7, 18-38.

Cook, D.C.,Buiks a, J.E., DeRousseau, C.J., Johanson,D.C., 1983. Vertebral pathology in the Afar aus alopithecines. Am. J. Phys. Antbropol. 64, 83-102.

Creed-Miles, M., Rosas, A., Kruszynski, R., 1996. Issues in the identification of Neandertal derivative raits at early post-natal stages. J. Hum. Evol. 30, $147-153$.

Cuenca-Bescós, G., Laplana, C., Canudo, J.I., Arsuaga, J.L., 1997. Small mammals from Sima de los Huesos. J. Hum. Evol. 33, 175-190.

Cunha, E., Ramirez Rozzi, F.V., Bermudez de Castro, J.M., MarinónTorres, M., Wasterlain, S.N., Sarmiento, S., 2004. Enamel hypoplasias and physiological stress in the Sima de los Huesos middle Pleistocene hominins. Am. J. Phys. Antbropol. 125, 22-231.

Dawson, J.E., Trinkaus, E., 1997. Vertebral osteoarthritis of the La Chapelleaux-Saints 1 Neanderthal. J. Archaeol. Sci. 24, 115-1021.

Escuredo, B., Sánchez, J.M., Borrás, F.X., Serrat, J., 2002. Estructura y función del cuerpo humano. McGraw-Hill, Interamericana, Madrid.

García, N., 2002. Los camívoros de los yacimientos Pleistocenos de la Sierra de Atapuerca. Ph.D. Dissertation, Universidad Complutense de Madrid.

García, N., Arsuaga, J.L., Torres, T., 1997. The carnivore remains from the Sima de los Huesos middle Pleistocene site (Sierra de Atapuerca, Spain). J. Hum. Evol. 33, 155-174.

Gómez, A., Carretero, J.M., Arsuaga, J.L., Marínez, I., Quam, R., Lorenzo, C, Gracia, A., García, N., Ortega, A.I, Rodríguez, L., 2004. El raquis de los humanos del yacimiento de la Sima de los Huesos (Sierra de Atapuerca, Burgos). In: Egocheaga, J.E. (Ed.), Biología de Poblaciones Humanas: Diversidad, Tiempo, Espacio. Dpto. de Biología de Organismos y Sistemas, Antropología Física, Universidad de Oviedo, Oviedo, pp. 283-293.

Gómez, A., Carretero, J.M., Rodríguez, L., García, R., Arsuaga, J.L., 2005 The cervical vertebrae from the Sima de los Huesos site (Sierra de Atapuerca, Burgos, Spain). Am. J. Phys. Anthropol. $4 \bullet$ (Suppl.), 107.

Gómez-Olivencia, A., 2005. Estudio de la colunma cervical de los humanos de la Sima de los Huesos (Sierra de Atapuerca, Burgos). Master's Thesis, Universidad Complutense de Madrid.

Gray, H., 1959. Anatomy of the Human Body. Lea and Febiger, Pbiladelphia

Grine, F.E., Pearson, O.M., Klein, R.G., Rightmire, G.P., 1998. Additional human fossils from Klasies River Mouth, South Africa. J. Hum. Evol. $35,95-107$

Heim, J.-L., 1976. Les Hommes fossiles de la Ferrassie. I. Le Gisement. Les Squelettes Adultes (Crâne et Squelette du Tronc). Masson, Paris.

Holliday, T.W., 2006. The vertebral columns. In: Trinkaus, E., Svoboda, J. (Eds.), Early Modern Human Evolution in Cen wal Europe. Oxford University Press, Oxford, pp. 242-294. 
Irish, J.D., 2000. The Iberomaurusian enigma: North African progenitor or dead end? J. Hum. Evol. 39, 393-410.

Kapandji, A.I., 1998. Fisiología Articular. 3. Tronco y Raquis. Editorial Médica Panamericana. Maloine, Madrid.

Latimer, B., Ohman, J.C., 2001. Axial dysplasia in Homo erectus. J. Hum. Evol. 40, A12.

Leakey, R.E.F., Walker, A.C., 1985. Further hominids from the Plio-Pleistocene of Koobi Fora, Kenya. Am. J. Phys. Antbropol. 67, 135-163.

Leroi-Gourhan, A., 1958. Étude des restes humains fossiles provenant des grottes d'Arcy-sur-Cure. Ann. Paléontol. 44, 87-148.

Love joy, C.O., Johanson, D.C., Coppens, Y., 1982. Elements of the axial skeleton recovere from the Hadar fornation: 1974-1977 collections. Am. J. Phys. Antbropol. 57, 631-635.

MacLamon, A.M., 1993. The vertebral canal. In: Walker, A., Leakey, R.E.F (Eds.), The Nariokotome Homo erectus Skeleton. Springer-Verlag, Berlin, pp. $359-390$.

MacLamon, A.M., Hewitt, G.P., 1999. The evolution of human speech: The role of enhance breathing con 341-363.

MacLamon, A.M., Hewitt, G.P., 2004. Increased breathing conmol: another factor in the evolution of human language. Evol. Antbropol. 13, 181-197.

Marino, E.A., 1995. Sex estimation using the first cervical vertebra. Am. J. Phys. Anthropol. 97, 127-133.

Marin, H., 1923. L'Homme fossile de la Quina. Librairie Octave Doin, Paris.

Marúnez, I., 1995. La base del cráneo y el hueso temporal en la evolución de los homínidos, con especial referencia a los fósiles de la Sierra de Atapuerca (Burgos). Ph. D. Dissertation, Universidad Complutense de Madrid.

Marínez, I., Arsuaga, J.L., 1997. The temporal bones from Sima de los Huesos middle Pleistocene site (Sierra de Atapuerca, Spain). A phylogeneric approach. J. Hum. Evol. 33, 283-318.

Marínez, I., Rosa, M., Arsuaga, J.L., Jarabo, P., Quam, R., Lorenzo, C., Gracia, A., Carretero, J.M., Bernúdez de Castro, J.M., Carbonell, E., 2004. Auditory capacities in middle Pleistocene humans from the Sierra de Atapuerca in Spain. Proc. Natl. Acad. Sci. U.S.A. 101, 9976-9981.

McCown, T.D., Keith, A., 1939. The Stone Age of Mount Cannel. The Fossil Human Remains from the Levalloiso-Mousterian. Clarendon Press, Oxford.

Meyer, M.R., 2005. Functional biology of the Homo erectus axial skeleton from Dmanisi, Georgia. Ph.D. Dissertation, University of Pennsylvania.

Meyer, M.R., Lordkipanitze, D., Vekua, 2066. Evidence for the anatomical capacity for spoken language in Homo erectus. Am. J. Phys. Antbropol. 42 (Suppl.), 13

Ogilvie, M.D., Hilton, C.E., Ogilvie, C.D., 1998. Lumbar anomalies in the Shanidar 3 Neandertal. J. Hum. Evol. 35, 597-610.

Pap, I., Tillier, A.-M., Arensburg, B., Chech, M., 1996. The Subalyuk Neanderthal remains (Hungary): a re-examination. Annales Historico-Naturales Musei Nationalis Hungarici 88, 233-27.

Pérez, P.-J., 2003. Recopilación de diagnósticos paleopatológicos en fósiles humanos, con casos relativos a homínidos de Atapuerca. In: Isidro, A
Malgosa, A. (Eds.), Paleopatología. La Enfennedad no Escrita. Masson, Barcelona.

Piveteau, J., 1966. La Grotte de Regourdou (Dordogne). Paléontologie humaine. Ann. Paléontol. 52, 163-194.

Radovcic, J., Smith, F.H., Trinkaus, E., Wolpoff, M.H., 1988. The Krapina Hominids. An Illus Catalog of Skeletal Collection. Mladost, Croatian Natural History Museum, Zagreb.

Rak, Y., Arensburg, B., 1987. Kebara 2 Neanderthal pelvis: first look at a complete inlet. Am. J. Phys. Anthropol. 73, 227-231.

Rak, Y., Kimbel, W.H., Hovers, E., 1994. A Neandertal infant from Amud Cave, Israel. J. Hum. Evol. 26, 313-324.

Rak, Y., Kimbel, W.H., Hovers, E., 1996. On Neandertal autapomorphies discemible in Neandertal infants: a response to Creed-Miles et al. J. Hum. Evol. 31, 155-158.

Ramírez Rozzi, F.V., Bermúdez de Castro, J.M., 204. Surprisingly rapid growth in Neanderthals. Nature 428, 936-939.

Rosas, A., Bastir, M., Marínez-Maza, C., Bennudez de Castro, J.M., 202. Sexual dimorphism in the Atapuerca-SH hominids: the evidence from the mandibles. J. Hum. Evol. 42, 451-474.

Scheuer, L., Black, S., 2006. Developmental Juvenile Osteology. Academic Press, San Diego.

Schiess, R., Haeusler, M., Langenegger, E., 2006. How pathological is the Nariokotome boy KNM-WT 15000 (Homo erectus)? Am. J. Phys. Anthropol. 42 (Suppl.), 159

Sládek, V., Trinkaus, E., Hillson, S.W., Holliday, T.W., 2006. The People of the Pavlovian. Skeletal Catalogue of the Gravetian Fossil Hominids from Dolní Věstonice and Pavlov. Academy of Sciences of the Czech Republic, Instute of Archaeology in Brno, Brno.

Smith, B.H., 1991. Dental development and the evolution of life history in Hominidae. Am. J. Phys. Anthropol. 86, 157-174.

Stewart, T.D., 1962. Neanderthal cervical vertebrae with special atten to the Shanidar Neanderthals from Iraq. Bibl. Primatol. 1, 13-154.

Trinkaus, E., 1983. The Shanidar Neandertals. Academic Press, New York.

Trinkaus, E., 1985. Pathology and the posture of the La Chapelle-aux-Saints Neandertal. Am. J. Phys. Antbropol. 67, 19-41.

Tubbs, R.S., Wellons, J.C., Banks, J., Blount, J.P., Oakes, W.J., 2002. Quantitative anatomy of the ransverse ligament tubercles. J. Neurosurg. Spine 97, 343-345.

Vanderneersch, B., 1981. Leshommesfossiles de Qafzeh (Isräel). CNRS, Paris.

Vandenneersch, B., Trinkaus, E., 1995. The postcranial remains of the Régourdou 1 Neandertal: the shoulder and ann remains. J. Hum. Evol. 28, 439-476.

Walker, A., Zimmennan, M.R., Leakey, R.E.F., 1982. A possible case of hypervitaminosis A in Homo erectus. Nature 296, 248-250.

Wescott, D.J., 2000. Sex variation in the second cervical vertebra. J. Forensic Sci. $45,462-466$.

Winters, J.M., Peles, J.D., 1990. Neck muscle activity and 3-D head kinematics uring quasi-static and dynamic tracking movements. In: Winters, J.M., Woo, S.L.-Y. (Eds.), Multiple Muscle Systems. Biomechanics and Movement Organization. Springer-Verlag, New York, pp. 461-480 